\title{
MENELUSURI “JEJAK" LAMBANG NEGARA REPUBLIK INDONESIA BERDASARKAN ANALISIS SEJARAH HUKUM
}

\author{
Turiman $^{1}$
}

\begin{abstract}
It is a fact, that the history of dealings with the past, or the events of the recent past and may not be repeated Search history require contemporaneous evidence, as a "recorded memory" is a very important and necessary in the proof of history. To express the need for honesty and a "sense of history, "because consciousness itself is the attitude history of psychiatric or mental attitude and state of mind which is the moral strength to fortify our conscience as a nation with the wisdom of discernment and wisdom in the face of the present and the future by learning and reflect on our past experiences. With such a perception, certainly in the academic study must have the moral courage to reveal the truth, the truth and the facts of history in a transparent and objective. Because an honest academic study is essentially the moral courage to fix the still dormant, straighten the crooked, conducting refresher correction and continuous, gradual, civilized and well mannered in the corridors of the constitutional and academic studies can be accountable. On the basis of such a view, it is wise if we look at the historical record of national statehood of the Republic of Indonesia in particular the history of the events of the past records, contribute to a child as well as the nation comes from the region of West Kalimantan are temporarily forgotten by the history of the nation, Sultan Hamid II. Actually, with reference to chronological facts of history can be seen in the work of nationality Sultan Hamid II as the gluing irreplaceable Indonesian nationalism in the history of this nation, the memories of the people of Indonesia, and is inherently the name of his native earth; West Kalimantan. For a brief overview of its history as the events following exposure. While serving Minister Zonder Porto Folio (1949-1950) he was fully active role and have a contribution to the history of the design drawing emblem of the Republic of Indonesia, such as the form of the picture now, as stated by Muhammad Hatta, 1978.
\end{abstract}

keywords: history of law, Sultan Hamid II, statement of Mohammad Hatta

\begin{abstract}
Abstrak
Adalah berkaitan suatu kenyataan sejarah, bahwa sejarah urusan dengan masa silam, atau kejadian-kejadian yang telah lewat dan tidak mungkin diulang kembali. Penelusuran sejarah memerlukan bukti-bukti sejaman, sebagai suatu "recorded memory" yang sangat penting serta diperlukan dalam pembuktian sejarah. Untuk mengungkapkannya perlu adanya kejujuran dan
\end{abstract}

\footnotetext{
${ }^{1}$ Penulis adalah Staf Pengajar Fakultas Hukum Universitas Tanjungpura, Pontianak. Alamat kontak: turiman@untan.ac.id.
} 
"kesadaran sejarah", karena kesadaran sejarah itu sendiri adalah sikap kejiwaan atau mental attitude dan state of mind yang merupakan kekuatan moral untuk meneguhkan hati nurani kita sebagai bangsa dengan hikmah kearifan dan kebijaksanaan, dalam menghadapi masa kini dan masa depan dengan belajar dan bercermin kepada pengalamanpengalaman masa lampau. Dengan persepsi yang demikian itu, tentunya dalam kajian sejarah hukum harus ada keberanian moral untuk mengungkapkan dengan jujur, kebenaran dan fakta sejarah secara transparan dan obyektif. Karena kajian akademis yang jujur pada hakekatnya adalah keberanian moral untuk membenahi yang masih terbengkalai, meluruskan yang bengkok, mengadakan koreksi dan penyegaran terus-menerus, secara gradual, beradab dan santun dalam koridor konstitusional serta kajian akademis yang dapat dipertanggungjawabkan. Atas dasar pandangan yang demikian itu, secara arif apabila kita melihat catatan sejarah nasional khususnya sejarah kenegaraan Republik Indonesia tercatatlah dalam peristiwa masa lampau, andil seorang anak bangsa yang sekaligus orang daerah berasal dari Kalimantan Barat yang sementara ini terlupakan oleh sejarahnya bangsanya, Sultan Hamid II. Sebenarnya dengan merujuk kronologis fakta sejarah dapat disimak adanya karya kebangsaan Sultan Hamid II yang merupakan alat perekat nasionalisme Indonesia yang tak ternilai dalam perjalanan sejarah bangsa ini, yang menjadi kenangan masyarakat Indonesia dan secara inheren mengharumkan nama bumi kelahirannya; Kalimantan Barat. Sewaktu menjabat Menteri Negara Zonder Porto Folio (1949-1950) danm secara pribadi beliau sepenuhnya aktif berperan dan memiliki konstribusi sejarah dalam merancang gambar lambang negara Republik Indonesia, seperti bentuk gambarnya sekarang ini, sebagaimana dinyatakan oleh Muhammad Hatta, 1978.

Kata kunci: sejarah hukum, Sultan Hamid II, pernyataan Muhammad Hatta

\section{Penduhulan}

\section{Sejarah Hukum Perancangan Lambang Negara}

Sebenarnya dengan merujuk kronologis fakta sejarah dapat disimak adanya karya kebangsaan Sultan Hamid II yang merupakan alat perekat nasionalisme Indonesia yang tak ternilai dalam perjalanan sejarah bangsa ini, yang menjadi kenangan masyarakat Indonesia dan secara inheren mengharumkan nama bumi kelahirannya; Kalimantan Barat. Sebagai gambaran singkat peristiwa sejarahnya sebagaimana paparan berikut ini.

Sewaktu menjabat Menteri Negara Zonder Porto Folio (1949-1950) beliau sepenuhnya aktif berperan dan memiliki konstribusi sejarah dalam merancang gambar lambang negara Republik Indonesia, seperti bentuk gambarnya sekarang ini, Rajawali Garuda Pancasila. Catatan serta dokumen proses perancangan lambang negara tersebut masih tersimpan dengan baik saat ini. 
Peran dan kontribusi sejarah itu dalam fakta sejarah nasional dan daerah seharusnya terangkat kepermukaan secara obyektif dan transparan. Adalah menjadi kewajiban kita untuk menegakan kebenaran dan keadilan sekaligus memahami amanah beliau sebagaimana pernah disampaikan oleh Sultan Hamid II (1974) sewaktu menyerahkan file arsip perancangan lambang negara kepada Mas Agung (Ketua Yayasan Idayu Jakarta) 18 Juli $1974:^{2}$

Mungkin ini adalah yang dapat saya sumbangkan kepada bangsa saya, dan "Mudah-mudahan sumbangan pertama saya (buku-buku dan dokumen file mengenai lambang negara) ini bermanfaat bagi negara yang dicintai oleh kita.

Sebagai warga bangsa yang besar dan generasi penerus sejarah bangsanya, sekaligus umat beriman sudah menjadi kewajiban kita untuk mengangkat kepermukaan fakta dan data sejarah secara jujur dan obyektif. Sebab kalau yang ingin kita inginkan adalah seseorang yang tidak pernah berbuat salah, maka kita tidak akan mempunyai tokoh sejarah secara utuh dan kita akan kesulitan menuliskan secara lengkap fakta sejarah perjuangan para tokoh bangsa di masa lampau. Padahal sejarah haruslah ditampilkan apa adanya sebagai pembawa warta kebenaran sejati dari peristiwa yang terjadi di masa lampau.

\section{Gagasan Awal Lambang Negara}

Sisi kesejarahan lambang negara itu dimulai pada tahun 1945 sebelum merdeka, tepatnya pada tanggal 13 Juli 1945 dalam rapat Panitia Perancang Undang-undang Dasar 1945, salah satu anggota Panitia bernama Parada Harahap mengusulkan tentang lambang negara. Usul tersebut disetujui oleh semua anggota, dan disepakati akan dibahas tersendiri kemudian, dalam bentuk Undang-undang istimewa yang mengatur secara khusus tentang lambang negara. Keterangan ini dapat ditemukan dalam naskah Persiapan Undang-Undang Dasar, 1945 jilid I yang disusun oleh Muhammad Yamin hal 263 dan lahirnya UndangUndang Dasar 1945 disusun oleh Soeripto yang menyatakan: ${ }^{3}$

Anggota Parada Harahap: Mengusulkan supaya disamping

bendera juga lambang negara (wapen). Semua setuju, tetapi dalam Undang-undang Istimewa.

Sesudah proklamasi kemerdekaan Republik Indonesia kemudian dibentuk Panitia Indonesia Raya,4 yang bertugas menyelidiki arti

\footnotetext{
${ }^{2}$ Tulisan Sultan Hamid II di atas kertas berlogo RTC, 1949 yang ditulis dihadapan H. Mas Agung, 18 Juli 1974 ketika penyerahan file lambang negara di Yayasan Idayu, Jakarta.

${ }^{3}$ Muhammad Yamin, "Naskah Persiapan Undang-Undang Dasar 1945”, Jilid I Cetakan Kedua, (Jakarta: Prapanca, 1967), hal. 263.
} 
lambang-lambang dalam peradaban bangsa Indonesia sebagai langkah awal untuk mempersiapkan bahan kajian tentang lambang negara. Panitia ini dikenal dengan nama Panitia Indonesia Raya yang diketuai oleh Ki Hajar Dewantoro dan sekretaris umum Muhammad Yamin. Tetapi panitia tersebut belum dapat menyelesaikan tugas akibat terjadinya peristiwa 3 Juli 1946 yang melibatkan Muhammad Yamin. ${ }^{5}$

Patut diperhatikan, bahwa pada tahun 1947 pernah diadakan sayembara rancangan lambang negara oleh Pemerintah yang diadakan oleh kementrian penerangan melalui organisasi seni Lukis seperti SIM (Seniman Indonesia Muda) Pelukis Rakyat) dan dalam catalog pameran Haris Purnomo 2006, yang bertajuk "Dibawah Sayap Garuda" terdapat ulasan Hendro Wiyanto selaku kurator yang mengulas perihal sayembara tersebut dengan judul: Tanda Lambang Garuda" 1951 yang berisi komentarnya tentang hasil rancangan sejumlah pelukis yang telah menuangkan gagasannya kedalam bentuk lambang negara, namun sayang sekali, menurut Oesman kebanyakan pelukis kurang paham hukumhukum kesejarahan dari tanda lambang negara. Hasilnya tidak satupun dari rancangan lambang negara Garuda Pancasila hasil lomba tersebut seperti yang kita kenal seperti sekarang ini. ${ }^{6}$

\section{Pembentukan Panitia Lambang Negara}

Setelah pelantikan Presiden Soekarno sebagai Presiden RIS 1949, 17 Desember 1949 di Siti Inggil Yogyakarta, maka pada tanggal 20 Desember 1949 berdasarkan Keputusan Presiden Republik Indonesia Serikat Nomor 2 Tahun 1949, Sultan Hamid II diangkat menjadi Menteri Negara Zonder Forto Polio. Dalam Kedudukan tersebut Sultan Hamid II dipercayakan untuk merencanakan perancangan lambang negara.7 Dalam

${ }^{4}$ G Sunaryo, Proses Terbentuknya Lambang Negara, "Majalah Forum Keadilan", No 19 Mei 1990, hal. 64.

${ }^{5}$ Peristiwa 3 Juli 1946 adalah peristiwa percobaan perebutan Kekuasaan di Yogyakarta yang dilakukan oleh kalangan persatuan perjuangan terhadap politik berunding clan menyerah (menurut anggapan oposisi) Kabinet Syahrir dan rencana kudeta itu rupanya diketahui pemerintah jauh sebelumnya. Akibatnya peristiwa itu seluruh Indonesia dinyatakan dalam bahaya (28 Juni 1946) clan seluruh Kekuasaan diserahkan kepada Presiden (29 Juni 1946). Pada Peristiwa itu 14 orang terdakwa diajukan kedepan Mahkamah Tentara Agung dan salah satunya adalah Muhammad Yamin yang dipersalahkan memimpin percobaan merobohkan Pemerintah yang sah dan dijatuhi hukuman 4 tahun penjara. Pada perayaan hari kemerdekaan 17 Agustus 1948 Presiden Soekamo memberikan grasi dan membebaskan mereka yang terlibat dalam peristiwa itu. Lihat Ensiklopedia Indonesia Edisi Khusus, (Jakarta: PT Ichtiar Van Hoeve, 1986), hal. 2671.

${ }^{6}$ Nanang R.Hidayat, ”Mencari Telur Garuda”, (Jakarta: Nalar, 2008), hal. 27.

${ }^{7}$ Lihat Buku "Peristiwa Sultan Hamid II", (Jakarta: Persaja, 1954), hal. 176. Sultan Hamid 11 menyatakan: Sebagai Menteri Negara saya hanya diserahi tugas menyiapkan gedung Parlemen dan membikin rencana buat lambang negara. Sampai saya ditangkap dan 
melaksanakan tugas yang dipercayakan oleh Presiden Soekarno, Sultan Hamid II secara pribadi mempersiapkan rancangan lambang negara dengan bentuk dasar burung Garuda yang memegang perisai Pancasila.

Berdasarkan transkrip rekaman dialog Sultan Hamid II dengan H. Mas Agung (1974), sewaktu menyerahkan file dokumen proses perancangan lambang negara. Dapat dikemukakan, bahwa "Ide Perisai Pancasila" itu muncul saat Sultan Hamid II sedang merancang lambang negara. Beliau (Sultan Hamid II) teringat ucapan Presiden Soekarno, hendaknya lambang negara tersebut melambangkan pandangan hidup bangsa, dasar negara Indonesia/ide Pancasila. Inilah saat-saat moment bersejarah dalam proses perancangan lambang negara Indonesia, dimana sila-sila dari dasar negara yaitu Pancasila divisualisasikan dalam bentuk simbol-simbol yang tergambar dalam lambang negara8.

Konstitusi Republik Indonesia Serikat (Konstitusi RIS) 1949 Pasal 3 ayat (3): Pemerintah menetapkan meterai dan lambang negara. Pada Sidang kedua Kabinet RIS tanggal 10 Januari 1950 dibentuk Panitia Teknis dengan nama Panitia Lambang Negara dibawah koordinator Menteri Negara Zonder Porto Folio Sultan Hamid II dengan susunan Panitia teknis:9 Muhammad Yamin10 (Ketua), Ki Hajar Dewantoro (anggota), M.A Pellaupessy, (anggota), Moh. Natsir (anggota), R.M. Ng Purbatjaraka (anggota). Panitia ini bertugas menyeleksi/ menilai usulanusulan rancangan lambang negara untuk dipilih dan diajukan kepada pemerintah.

Merujuk keterangan Mohammad Hatta (Buku Bung Hatta Menjawab) untuk melaksanakan keputusan sidang kabinet tersebut menteri Priyono11 melaksanakan sayembara lambang negara. Hasil sayembara lambang negara itu ada dua (2) gambar rancangan lambang negara yang terbaik yaitu dari Sultan Hamid II dan Muhammad Yamin. Dalam proses selanjutnya yang diterima oleh pemerintah adalah hasil

kemudian ditahan tak ada lain tugas saya.

${ }^{8}$ Hasil wawancara dengan sekretaris Pribadi Sultan Hamid II, Max Yusuf Alkadrie, 11 Oktober 2012.

${ }^{9}$ G. Sunaryo, Proses Terbentunya Lambang Negara, "Forum Keadilan", No 19 (Mei 1990), hal. 64, lihat juga transkrip penjelasan Sultan Hamid II kepada wartawan Solichim Salam, 15 April 1967 yang disalin kembali oleh sekretaris pribadi Sultan Hamid II: Max Yusuf Al-Kadrie yang sekarang menjabat Ketua Yayasan Sultan Hamid II Jakarta.

${ }^{10}$ Mr Prof. Mohammad Yamin S.H. (lahir di Tawali, Sawahlunto, Sumatera Barat, 24 Agustus 1903-meninggal di Jakarta, 17 Oktober 1962 pada umur 59 tahun) adalah sastrawan, sejarawan, budayawan, politikus, dan ahli hukum yang telah dihormati sebagai Pahlawan Nasional Indonesia. Ia merupakan salah satu perintis puisi modern Indonesia dan pelopor Sumpah Pemuda sekaligus "pencipta imaji keindonesiaan" yang mempengaruhi sejarah persatuan Indonesia

${ }^{11}$ Prijono (lahir di Yogyakarta, 20 Juli 1905-meninggal 6 Maret 1969 pada umur 63 tahun) adalah Menteri Pendidikan dan Kebudayaan Indonesia periode 1950 hingga tahun 1966. 
rancangan Sultan Hamid II. Adapun yang dari Muhammad Yamin ditolak, karena ada sinar-sinar matahari dan menampakan sedikit banyak disengaja atau tidak, pengaruh Jepang.

Keterangan Mohammad Hatta itu selengkapnya adalah: ${ }^{12}$

..... Patut pula ditambahkan sebagai catatan bahwa lambang dengan tulisan yang mempunyai arti yang demikian mendalam itu, dipadukan menjadi seperti sekarang ini, dengan melalui sayembara waktu RIS dulu dan dilaksanakan oleh Menteri Priono, Banyak gambar yang masuk waktu itu, tetapi yang terbaik akhirnya ada dua buah, satu dari Muhammad Yamin dan yang satu lagi dari Sultan Hamid. Yang diterima oleh Pemerintah dan DPR adalah dari Sultan Hamid yakni seperti sekarang ini. Adapun dari Muhammad Yamin ditolak, karena disana ada gambar sinar-sinar matahari dan menampakan sedikit banyak disengaja atau tidak pengaruh Jepang. Saya berpendapat bahwa apa yang ada sekarang itu, seperti uraian saya tadi sudah tepat dan bernilai abadi bagi kehidupan negara dan bangsa Indonesia.

Setelah terpilihnya rancangan lambang negara rancangan Sultan Hamid II oleh pemerintah tersebut, proses selanjutnya adalah diadakan dialog intensif antara perancang lambang negara (Sultan Hamid II dengan Presiden RIS: Soekarno dan Perdana Menteri RIS Mohammad Hatta serta anggota Panitia Lambang Negara), untuk menyempurnakan rancangan tersebut.

Adapun masukan penyempurnaan pertama sebagaimana dinyatakan Mohammad Hatta dalam buku Bung Hatta Menjawab dan Sultan Hamid II (transkrip rekaman dialog Sultan Hamid II dan Mas Agung, 1974) ialah adanya kesepakatan beliau bertiga (Sultan Hamid II, Soekamo, Mohammad Hatta) memenuhi usulan Presiden Soekarno: Mengganti pita yang yang dicengkeram Garuda, ${ }^{13}$ yang semula adalah pita merah putih menjadi pita berwarna putih dengan tambahan seloka "Bhinneka Tunggal Ika". Sebab warna merah putih dianggap sudah terwakili dalam warna dasar perisai Pancasila rancangan Sultan Hamid II tersebut. ${ }^{14}$

Pertanyaan historis empirik dari mana bahan dasar dalam perancangan gambar lambang negara oleh Sultan Hamid II. Sejarah

\footnotetext{
12 "Bung Hatta Menjawab", (Wawancara Muhammad Hatta dengan Z. Yasni) Cetakan Ketiga, (Jakarta: Gunung Agung, 1978), hal. 108.

${ }^{13}$ Transkrip penjelasan Sultan Hamid II kepada wartawan Solichim Salam, yang disalin kembali oleh sekretaris pribadi Sultan Hamid II Max Yusuf Al-Kadrie, 15 April 1967.

14 Wawancara dengan U’Un Mahdar Asmadi, 11 Februari 2012, yang pernah melakukan wawancara langsung dengan H.Mas Agung, 1985, ketika Sultan Hamid II menyerahkan file lambang negara kepada Yayasan Idayu Jakarta, 18 Juli 1974.
} 
mencatat, bahwa pada tanggal 26 Januari 1950 Ki Hajar Dewantoro (dari Yogyakarta) mengirimkan balasan surat kepada Sultan Hamid II melalui sekretaris Dewan Menteri RIS (Z. Yahya) yang isinya menunjuk Muhammad Yamin untuk memberikan masukan mewakili beliau kepada Panitia Lambang Negara dan surat turunannya telah disampaikan kepada Menteri Negara Sultan Hamid II tanggal 1 Februari 1950 No XXX/ 202, Perihal Panitia Lambang Negara.

Isi surat balasan Ki Hajar Dewantoro kepada Sultan Hamid II itu sebagai berikut: ${ }^{15}$

Yogyakarta, 26 Januari 1950

“Merdeka!

Menarik kawat paduka Tuan hari ini, yang bermaksud atas Nama Yang Mulia Menteri Negara R.I.S Sri Sultan Hamid ke II mengundang saya pergi ke Jakarta untuk keperluan "Panitia Lambang Negara", maka dengan ini saya memberitahukan kepada Paduka Tuan:

1. Bahwa pada waktu ini ada beberapa keperluan serta pekerjaan yang penting bagi saya di Yogyakarta, sehingga sukariah bagi saya untuk pergi ke Jakarta.

2. Bahwa kalaulah benar saya diangkat menjadi anggota dari pada "Panitia Lambang Negara RIS" sebenarnya tentang rancangan membuat lambang itu sudah pemah dilakukan penyelidikan yang seksama oleh "Panitia Indonesia Raya", yang dulu dibentuk oleh Pemerintah Republik Indonesia Raya, yang saya menjadi ketuanya, sedangkan saudara Mr Muhammad Yamin duduk menjadi sekretaris umum. Dalam penyelidikan itu saudara Mr Muhammad Yamin sendiri lebih mengetahui segala apa yang direncanakan oleh "Panitia Indonesia Raya " tersebut dari pada saya sendiri.

3. Bahwa kalau sungguh-sungguh diperlukan pendapat atau nasehat saya dalam Panitia lambang Negara R.I.S. sekarang ini, maka cukuplah kiranya ketua Panitia Mr Muhammad Yamin atau anggota lainnya pergi ke Yogya untuk bertukar pikir dengan saya, atau cukuplah barangkali, bisa saya hanya mengirimkan nasehat atau usul dengan tertulis kepada Panitia di Jakarta.Dalam hal ini alangkah baiknya, jika Panitia mengirimkan pertanyaan-pertanyaan yang tertentu kepada saya untuk saya jawab.

Demikianlah keterangan saya atas isi kawat, yang hari ini saya kirimkan kepada Paduka Tuan, sebagai balasan kawat Paduka Tuan kepada saya.

Hormat Salam.... Merdeka

${ }^{15}$ Dokumen Surat Dari Ki Hajar Dewantoro kepada Sultan Hamid II, tgl 26 Januari 1950, seperti yang dinyatakan juga oleh Sultan Hamid II dalam transkrip penjelasan Sultan Hamid II kepada wartawan Solichim Salam, yang disalin kembali oleh sekretaris pribadi Sultan Hamid II Max Yusuf Al-Kadrie, Jakarta, 1970. 
Dewantoro

Sultan Hamid II sendiri menyatakan dalam transkripnya, sebagai berikut: ${ }^{16}$

Saja membuat sketsa berdasarkan masukan Ki Hadjar Dewantara dengan figur Garuda dalam mitologi jang dikumpulkan oleh beliau dari beberapa tjandi di Pulau Djawa dikirim beliau dari Djogjakarta, dan tidak lupa saja djuga membandingkan salah satu simbol Garuda jang dipakai sebagai Lambang Kerajaan Sintang, Kalimantan Barat, tetapi hanja merupakan salah satu bahan perbandingan antara bentuk Burung Garuda jang berada di candi-candi di Djawa dengan luar Djawa.Karena secara historis Kerajaan Sintang masih ada hubungan dengan Kerajaan Madjapahit, seperti di dalam Legenda Daradjuanti dengan Patih Lohgender, demikian keterangan Panglima Burung ${ }^{17}$ menjelaskan kepada saja di Hotel Des Indes awal Februari 1950."

Selanjutnya berdasarkan bahan dasar yaitu berupa gambar-gambar sktesa figur garuda dari berbagai candi di Jawa yang dikirim oleh Ki Hajar Dewantoro, maka Sultan Hamid II membuat berbagai sketsa rancangan lambang negara RIS, sebagaimana yang dipercayakan oleh Presiden Soekarno ${ }^{18}$ sebagai pelaksanaan Pasal 3 ayat (3) Konstitusi RIS $^{19} 1950$ dan patut diketahui, bahwa secara historis yuridis dan historis

\footnotetext{
${ }^{16}$ Transkrip penjelasan Sultan Hamid II kepada wartawan Solichim Salam, yang disalin kembali oleh sekretaris pribadi Sultan Hamid II Max Yusuf Al-Kadrie, 15 April 1967.

${ }^{17}$ Panglima Burung, adalah tokoh Adat Suku Dayak asal Kecamatan Meliau, Kabupaten Sintang, Provinsi Kalimantan Barat. Panglima Burung terlibat di dalam Perang Majang Desa Melawan Jepang. Peran Panglima Burung dalam berperang melawan Jepang, bisa dibaca di buku: Sejarah Perang Majang Desa Melawan Jepang, ditulis S. Jacobus E Frans L. BA, terbitan Kantor Wilayah Pendidikan dan Kebudayaan Daerah Tingkat I Kalimantan Barat tahun 1981.
}

${ }^{18}$ Lihat Buku "Peristiwa Sultan Hamid II", (Jakarta: Persaja, 1954), hal. 176. Sultan Hamid II, menyatakan: "Sebagai Menteri Negara saya hanya diserahi tugas menyiapkan gedung Parlemen dan membikin rencana bust lambang negara. Sampai saya ditangkap dan kemudian ditahan tak ada lain tugas saya". Dalam transkrip Sultan Hamid II 15 April 1967 juga dinyatakan hal yang sama "Saja sedjudjurnya hanya berupaja mengangkat kembali lambang-lambang/simbol-simbol jang ada di peradaban klasik bangsa Indonesia bersama anggota Panitia Lambang Negara itu sebenarnya semangat gorong-royong lewat perentjanaan gambang Lambang Negara RIS sebagaimana ditugaskan kepada saja selaku Menteri Zonderportofolio. Karena memang tidak ada tugas lain untuk saja sebagai Menteri Selain merentjanakan lambang negara dan menjiapkan gedung parlemen RIS, saja berharap agar kelak bangsa ini ditjintai oleh kita semua bertekad untuk memadjukan-membangun bersama”.

${ }^{19}$ Bagian III Lambang dan Bahasa Negara Pasal 3 ayat (3) Konstitusi RIS, 1950: Materai dan Lambang Negara ditetapkan oleh Pemerintah. 
empirik lambang negara yang dirancang tersebut adalah dimaksudkan sebagai Lambang Negara RIS.

Kemudian selanjutnya dari berbagai masukan dari anggota Panitia Lambang Negara dari Ki Hajardewantoro dan Muhammad Yamin, serta Soekarno, maka Sultan Hamid II membuat sketsa rencana lambang negara dengan mengambil figur burung Garuda dalam peradaban bangsa Indonesia, sebagaimana dijelaskan oleh Sultan Hamid II dalam transkripnya, yaitu: ${ }^{20}$

Saja putuskan tjiptaan pertama berbentuk figur burung Garuda jang memegang Pantja-Sila, seperti masukan Ki Hajar Dewantara jang diambil dari mitologi garuda pada peradaban Bangsa Indonesia, tetapi ketika gambar lambang negara ini saja bawa ke dalam Rapat Panitia Lambang Negara, 8 Februari 1950, ternjata ditolak oleh anggota Panitia Lambang Negara RIS lain, karena ada beberatan dari dari M. Natsir ada tangan manusia jang memegang perisai berkesan terlalu mitologi dan feodal, djuga keberatan anggota lain $R$. M. Ng. Purbatjaraka terhadap djumlah bulu ekor tudjuh helai, terus terang jang mengusulkan tudjuh helai ini adalah Mr. M. Jamin. Untuk itu saja mintakan dalam rapat, Mr. M. Jamin ketika itu mendjelaskan makna tudjuh helai bulu ekor selaku Ketua Panitia Lambang Negara, dan ada kesepakatan untuk diubah mendjadi 8 helai bulu ekor, sebagai tjandra sengkala/identitas negara proklamasi 17 Agustus 1945 atas usulan M. A. Pellaupessy jang menurut beliau tak boleh dilupakan.

Mengacu pada penjelasan Sultan Hamid II di atas, maka berdasarkan hasil penelitian hal tersebut dapat dibuktikan dengan dokumen hasil coretan tangan Sultan Hamid II yang diserahkan ke H Mas Agung, 18 Juli 1974 dan saat ini tersimpan dengan baik di Yayasan Mas Agung dahulu berada di Yayasan Idayu Jakarta.

Selanjutnya pada tanggal 8 Februari 1950 rancangan final gambar lambang negara yang dirancang oleh Sultan Hamid II kemudian dibawa kedalam rapat Panitia Lambang Negara. Pada rapat Panitia tersebut gambar rancangan Sultan Hamid II mendapat masukan dan kritikan dari suatu Partai Islam (Masyumi) yang diwakili oleh Mohammad Natsir untuk dipertimbangkan, karena adanya keberatan terhadap gambar figur burung Garuda dengan tangan dan bahu manusia yang memegang perisai. Gambaran demikian juga dianggap bersifat mitologis khayalan dan terkesan mitologi dan feodal.

\footnotetext{
${ }^{20}$ Transkrip penjelasan Sultan Hamid II kepada wartawan Solichim Salam, yang disalin kembali oleh sekretaris pribadi Sultan Hamid II Max Yusuf Al-Kadrie, 15 April 1967.
} 
Mengenai gambaran bentuk gambar lambang negara yang dirancang oleh Sultan Hamid II juga dijelaskan di dalam buku Muhammad Yamin: 6000 Tahun Sang Merah Putih: ${ }^{21}$

Burung Garuda itu memegang sebuah perisai yang terbagi atas lima bidang, yang keseluruhannya melukiskan ajaran Pancasila yang menjadi dasar filosofi kenegaraan sejak proklamasi: Peri Ketuhanan Yang Maha Esa, Peri Kebangsaan, Peri Kerakyatan, Peri Kemanusiaan dan Peri Keadilan. Semboyan yang banyaknya 17 aksara itu Bhinneka Tunggal Ika berasal dari pujangga Tantular yang mengarang kitab Sutasoma pads zaman emas sekeliling patih Gadjah Mada dan negara Hayam Wuruk pads pertengahan abad XIV. Adapun arti seloka Jawa lama itu: Walaupun berbeda-beda atau berlainan agama, keyakinan dan tinjauan, tetapi tetap tinggal bersatu atau dalam bahasa latin le pluribus unum"

Secara analisis semiotika dengan pendekatan historis empirik jika dihubungkan dengan figur gambar Garuda dalam mitologi bangsa Indonesia sebagaimana tergambar diberbagai candi-candi maupun karya sastra digambar dalam bentuk makhluk setengah burung setengah manusia.

Presiden Soekarno pernah menyitir tentang mitologi Garuda " $A k u$ adalah Garuda, burung milik Wisnu yang membentangkan sayapnya menjulang tinggi di atas kepulauanmu." Bait sajak karya Raden Mas Noto Soeroto dalam buku Wayang-liederen yang dikutip oleh Presiden Soekarno ketika diminta memberikan nama untuk maskapai penerbangan Indonesia. $^{22}$

Sultan Hamid II sebagai perancang gambar lambang negara kemudian memperbaiki hasil rancangan tahap pertama tersebut, sebagaimana dijelaskan dalam transkrip Sultan Hamid II: ${ }^{23}$

Akhirnya setelah penolakan itu saja mengambil inisiatif pribadi untuk memperbandingkan dengan lambang-lambang negara luar, khususnja negara-negara Arab, seperti Yaman, Irak, Iran, Mesir, ternjata menggunakan figur burung Elang Radjawali, djuga seperti Negara Polandia jang sudah sejak

${ }^{21}$ Muhammad Yamin, 6000 Tahun Sang Merah Putih, Siguntang, 1954. halaman 168.

22 Zaini Rakhman, Garuda, Mitos dan Faktanya di Indonesia, <http://archive.blogspot.com/2012/09/kisah-sang-lambang-negara-burung-garuda>, diakses tanggal 20 September 2013.

${ }^{23}$ Transkrip Sultan Hamid II, kepada wartawan Solichim Salam, yang disalin kembali oleh sekretaris pribadi Sultan Hamid II Max Yusuf Al-Kadrie, 15 April 1967. 
ratusan tahun djuga menggunakan burung Elang Radjawali seperti jang saja jelaskan di atas dalam kemeliterannya.

Karena sosoknja lebih besar/gagah dari burung elang jang ada di Djawa dan ini simbolisasi lambang tenaga pembangunan/creatif vermogen negara dengan harapan Negara Republik Indonesia Serikat (RIS) mendjadi negara jang besar dan setara dengan negara-negara di dunia, sudah mendjadi kewadjarawan dan demikian seharusnya.

Selandjutnya gambar lambang negara saja bisa diterima oleh anggota Panitia Lambang Negara, demikian djuga lambang negara rantjangan Mr Mohammad Jamin jang kemudian kami serahkan bersama kepada Perdana Menteri Mohammad Hatta, untuk dibawa ke Pemerintah dan sidang Parlemen RIS untuk dipilih. Alhamdulillah gambar rantjangan saja jang diterima, 10 Februari 1950 dan esoknja untuk pertama kali diperkenalkan kepada chalajak ramai di Hotel Des Indes, jang kemudian pada rapat Parlemen RIS bersama Pemerintah ditetapkan Parlemen RIS sebagai Lambang Negara RIS, pada tanggal 11 Februari 1950.

Walaupun demikian, ada masukan beberapa waktu kemudian dari Paduka Jang Mulia Presiden Soekarno ketika beliau sedang berpidato kenegaraan, 20 Februari 1950 melihat lambang negara tersebut jang tergantung di belakang podium Parleman Istana Merdeka Pedjambon, karena kepala burung Radjawali tidak 'berdjambul' dan terlihat 'gundul'. Paduka Jang Mulia meminta saja untuk memperbaiki bentuk kepala, kemudian saja mengubah bagian kepala mendjadi berdjambul, kemudian oleh Kementerian Penerangan RIS atas perintah Paduka Jang Mulia Presiden Soekarno kepada pelukis Dullah $^{24}$, untuk melukis kembali lambang negara tersebut.

Kemudian lukisan itu saja potret dalam bentuk hitam putih untuk dikoreksi kembali oleh Paduka Jang Mulia Presiden Soekarno dan ternjata masih ada keberatan dari beliau, jakni bentuk tjakar kaki masih ada jang mentjengkram seloka Bhinneka Tunggal Ika dari arah belakang sepertinya terbalik, saja mentjoba mendjelaskan kepada Paduka Jang Mulia, memang begitu burung terbang membawa sesuatu seperti keadaan alamiahnja.

Tetapi menurut Paduka Jang Mulia, seloka ini adalah hal jang sangat prinsip, karena memang sedjak semula merupakan usulan beliau sebagai ganti rentjana pita merah putih jang

${ }^{24}$ Dullah, adalah pelukis di Istana Kepresidenan selama Soekarno menjadi Presiden. 
menurut beliau sudah terwakili pada warna perisai. Selandjutnya meminta saja untuk mengubah bagian tjakar kaki mendjadi mentjengkram pita/mendjadi ke arah depan pita agar tidak 'terbalik' dengan alasan ini berkaitan dengan prinsip 'djatidiri' bangsa Indonesia, karena merupakan perpaduan antara pandangan 'federalis' dan pandangan 'kesatuan' dalam Negara RIS.

Mengertilah saja pesan filosofis Paduka Jang Mulia itu, djadi djika 'bhinneka' jang ditondjolkan itu maknanja perbedaan jang menondjol dan djika 'keikaan' jang ditondjolkan itulah kesatuan repulbik jang menondjol, djadi keduanja harus disatukan, karena ini lambang Negara RIS jang di dalamnja merupakan perpaduan antara pandangan 'federalis' dan pandangan 'kesatuan' haruslah dipegang teguh sebagai 'djatidiri' dan prinsip berbeda-beda pandangan tanpai satu djua' e-pluribus unum'.

Walaupun saja harus sudah pajah membuat sketsa kembali untuk pembetulan badan tjakar kaki itu, tetap saja mengerti ini hal bagian jang sangat penting dalam lambang Negara RIS. Karena mengandung tiga konsep lambang sekaligus, jakni pertama, burung Radjawali-Garuda Pantja-Sila jang menurut perasaan Bangsa Indonesia berdekatan dengan Burung Garuda dalam mitologi, kedua perisai ide Pantja-Sila berthawaf'/gilir balik, dan ketiga, seloka Bhinneka Tunggal Ika jang tertulis dalam pita warna putih.

Berdasarkan penjelasan Sultan Hamid II diatas, yang menyatakan, bahwa setelah ada keberatan terhadap figur garuda sebagai lambang negara RIS yang terkesan terlalu mitologis dan feodal, karena ada bahu dan tangan manusia yang memegang perisai Pancasila, maka Sultan Hamid II kemudian melakukan perbandingan dengan negara-negara lain di dunia yang menggunakan figur burung elang Rajawali.

Dengan demikian secara semiotika hukum dengan pendekatan historis empirik ada sebuah pergeseran figur burung yang dijadikan lambang negara RIS, yaitu figur pertama adalah figur burung Garuda dalam mitologi bangsa Indonesia, kemudian setelah Sultan Hamid II melakukan perbandingan figur yang dipilih untuk selanjutnya adalah figur burung elang Rajawali.

Paparan diatas dijelaskan oleh Sultan Hamid II dalam transkripnya sebagai berikut:

Sedangkan mengapa diberi nama Burung Elang Radjawali Garuda Pantja-Sila, karena saja menghargai latar belakang gambar jang saja tjiptakan pertama mengambil figur burung Garuda memegang perisai Pantja-Sila, berubah mendjadi figur Burung Elang Radjawali (cetak tebal dari peneliti) jang 
dikalungkan perisai Pantja-Sila agar prosesi bangsa ini djangan melupakan peradaban bangsanja dari mana dia berasal/djangan sampai melupkakan sedjarah puntjak-puntjak peradabannja, seperti pesan Paduka Jang Mulia.

Artinya secara semiotika hukum ada sebuah pergeseran figur burung yang dijadikan lambang negara atau dengan kata lain ada dua tahapan rancangan lambang negara sampai dengan ditetapkan oleh Pemerintah Republik Indonesia secara de facto, yaitu tahap pertama adalah figur burung garuda dalam mitologi kemudian pada tahap kedua secara de jure adalah figur burung Elang Rajawali dalam bentuk alamiah.

Secara teks verbal dengan pendekatan historis yuridis atau dengan analisis hermenuetik yang menurut Carl Braaten adalah ...the science of refleting on howa a word or an event is past time and culture may be understood and become exixtentially meaningful in our present situation $^{25}$ Artinya hermeuetik dipakai sebagai metode pembacaan atas teks dalam kerangka untuk menemukan dimensi-dimensi baru yang belum ditemukan sebelumnya, yang belum terpikirkan atau tidak terpikirkan atau memperkuat temuan-temuan sebelumnya. Namun, secara umum hermenuetik biasanya dipakai untuk menjembatan antara masa lalu dan masa kini, sehingga pendekatan historis juga diperlukan dalam kajian ini.

Pendekatan historis dimaksud adalah dengan menggunakan historis yuridis dalam peraturan perundang-undangan dalam hal ini mengacu pada penjelasan Peraturan Pemerintah Nomor 66 Tahun 1951 Tentang Lambang Negara yang menyatakan:

Lukisan Garuda diambil dari benda Peradaban Indonesia seperti hidup dalam Mityologi, symbologi dan Kesusasteraan Indonesia dan seperti pula tergambar pada beberapa candi sejak abad ke 6 sampai abad ke 16. (Penjelasan Pasal 1)

Burung Garuda dari mytologi menurut perasaan Indonesia berdekatan dengan burung Elang Rajawali. Burung itu dilukiskan di candi Dieng, Prambanan dan Penataran. Ada kalanya dengan memakai lukis berupa manusia dengan berparuh burung dan bersayap (Dien): dicandi Prambanan dan di candi Jawa Timur seperti berparuh panjang berambut raksasa dan bercakar. Lihatlah lukisan garuda dicandi mendut, Prambanan dan candi-candi Sukuh. Kedal di Jawa Timur. Umumnya maka garuda terkenal baik oleh archeologi, kesusasteraan dan mitologi Indonesia. Lencana Garuda pernah dipakai oleh prabu Air Langga pada abad kesebelas dengan bernama Garudamukha. Menurut patung Belahan beliau dilukiskan dengan mengendarai seekor garuda.

${ }^{25}$ Carl Braaten, “History Hermueutics”, (Philadelphia: Fortress, 1966), hal. 31. 
Demikian juga dalam teks hukum pada penjelasan Pasal 46 UndangUndang Nomor 24 Tahun 2009 Tentang Bendera, Bahasa, dan Lambang Negara Serta Lagu Kebangsaan dalam Penjelasan 46 menyatakan: Yang dimaksud dengan "Garuda Pancasila" adalah Lambang berupa burung garuda yang sudah dikenal melalui mitologi kuno, yaitu burung yang menyerupai Burung Elang Rajawali.

Presiden Soekarno dalam Pidato Kenegaraan 22 Juli 1958 menyatakan secara tegas:

Saudara-saudara, Lihatlah Lambang Negara kita dibelakang ini alangkah megahnya, alangkah hebat dan cantiknya.

Burung Elang Rajawali, garuda yang sayap kanan dan sayap kirinya berelar 17 buah, ekor yang berelar 8 buah, tanggal 17, bulan 8 dan berkalungkan perisai yang diatas perisai itu tergambar Pancasila.....

Pertanyaan yang perlu diajukan dengan mengacu pada dokumen di atas dan teks yang tertulis dalam peraturan perundangan serta pernyataan Presiden Soekarno, Sultan Hamid II, yaitu apakah gambar lambang negara Republik Indonesia saat ini mengambil figur burung Garuda dalam mitologi atau mengambil figur burung Elang Rajawali ?

Jawaban atas pertanyaan itu memberikan sebuah refleksi dari pendapat umum yang menyatakan, bahwa lambang negara republik Indonesia adalah burung Garuda, atau dalam bahasa konstitusi UUD 1945 hasil amandemen menyatakan, bahwa lambang negara ialah Garuda Pancasila dengan semboyan Bhinneka Tunggal Ika ${ }^{26}$, sedangkan secara analisis semiotika hukum adalah figur burung elang Rajawali. Ini memberikan bukti bahwa antara fakta sejarah dengan yang dirumuskan oleh hukum negara berbeda.

Makna secara hermenuetika historis memberikan paparan, bahwa setiap realitas kenegaraan dalam kaitannya dengan lambang negara yang ada saat ini telah terjadi sebuah pemahaman yang terekonstruksi dari pandangan mitologi, yaitu mitologi Garuda. Sedangkan bentuk gambarnya adalah figur burung Elang Rajawali atau burung dalam bentuk alamiah, oleh karena itu secara semiotika hukum Sultan Hamid II menyatakan secara cerdas dalam transkripnya sebagai berikut: ${ }^{27}$

...sedangkan mengapa diberi nama Burung Elang Radjawali

Garuda Pantja-Sila, karena saja menghargai latar belakang

gambar jang saja tjiptakan pertama mengambil figur burung

${ }^{26}$ Pasal 36 A UUD Neg Ri 1945 hasil amandemen kedua.

27 Nama Rajawali Garuda Pancasila, adalah nama yang sering disebut oleh Sultan Hamid II, dalam transkrip penjelasan Sultan Hamid II kepada wartawan Solichim Salam, yang disalin kembali oleh sekretaris pribadi Sultan Hamid II Max Yusuf Al-Kadrie, 15 April 1967, hal. 6 . 
Garuda memegang perisai Pantja-Sila, berubah mendjadi figur Burung Elang Radjawali jang dikalungkan perisai Pantja-Sila agar proses bangsa ini djangan melupakan peradaban bangsanja dari mana dia berasal/djangan sampai melupakan sedjarah puntjak-puntjak peradabannja, seperti pesan Paduka Jang Mulia.

Kemudian pada bagian lain menyatakan: ${ }^{28}$

Saja sedjudjurnya hanya berupaja mengangkat kembali lambang-lambang/simbol-simbol jang ada di peradaban klasik bangsa Indonesia bersama anggota Panitia Lambang Negara itu sebenarnya semangat gorong-royong lewat perentjanaan gambang Lambang Negara RIS sebagaimana ditugaskan kepada saja selaku Menteri Zonderportofolio. Karena memang tidak ada tugas lain untuk saja sebagai Menteri Selain merentjanakan lambang negara dan menjiapkan gedung parlemen RIS, saja berharap agar kelak bangsa ini ditjintai oleh kita seтиa bertekad untuk memadjukan-membangun bersama.

Pernyataan di atas ada pesan filosofis, bahwa bangsa Indonesia melalui lambang negara yang lukisannya diambil dari lukisan Garuda dalam mitologi yang ada dalam peradaban bangsa Indonesia tidak menjadi bangsa Indonesia melupakan peradaban bangsanya, namun dengan mengambil figur burung elang Rajawali seperti lambang negara yang di dunia mengandung pesan untuk memajukan bangsanya selaras dengan peradaban dunia dan bernilai universal.

\section{Lambang Negara Ditetapkan Kabinet RIS}

Tanggal 10 Februari 1950 Sultan Hamid II mengajukan rancangan gambar lambang negara yang telah disempurnakan berdasarkan aspirasi yang berkembang dan melakukan perbandingan dengan lambang negara di dunia yang juga menggunakan figur burung elang Rajawali, sehingga tercipta bentuk Rajawali Garuda Pancasila. ${ }^{29}$ Disini terjadi pergeseran bentuk kepala burung yang digambar dalam bentuk alami menyerupai kepala burung Rajawali yang perkasa, dan perisai Pancasila digantungkan atau dikalungkan pada leher Rajawali Garuda Pancasila. Presiden Soekarno kemudian menyerahkan rancangan kedua Sultan Hamid II tersebut kepada Kabinet RIS melalui Perdana Menteri RIS, yaitu Mohammad Hatta, 10 Februari $1950^{30}$

${ }^{28}$ Tanskrip penjelasan Sultan Hamid II kepada wartawan Solichim Salam, yang disalin kembali oleh sekretaris pribadi Sultan Hamid II Max Yusuf Al-Kadrie, 15 April 1967, hal 9.

${ }^{29}$ Nama Rajawali Garuda Pancasila, adalah nama yang sering disebut oleh Sultan Hamid II, dalam transkrip penjelasan Sultan Hamid II kepada wartawan Solichim Salam, yang disalin kembali oleh sekretaris pribadi Sultan Hamid II Max Yusuf Al-Kadrie, 15 April 1967.

${ }^{30}$ Transkrip Sultan Hamid II, ibid halaman 4 
Tanggal 11 Februari 1950 rancangan lambang negara yang dibuat Sultan Hamid II ditetapkan oleh Pemerintah/Kabinet IIS $^{31}$ dan diresmikan pemakaiannya dalam Sidang Kabinet dan Parlemens RIS yang dipimpin Perdana Menteri RIS Mohammad Hatta yang mengambil tempat di gedung Penjabon atau Gedung Parlemen RIS atau sekarang Gedung Pancasila yang berada di komplek Kementrian Luar Negeri. Inilah saat pertama bangsa Indonesia mempunyai lambang negara, yang merupakan karya kebangsaan yang diramu dari berbagai aspirasi, oleh seorang anak bangsa Indonesia Sultan Hamid II dan keterangan ini diperkuat oleh Bung Hatta dalam buku Bung Hatta Menjawab: ${ }^{32}$

Semboyan Bhinneka' Tunggal Ika adalah ciptaan Bung Karno, setelah kita merdeka, semboyan itu kemudian diperkuat dengan lambang yang dibuat oleh Sultan Abdul Hamid Pontianak dan diresmikan pemakaiannya oleh Kabinet RIS tanggal 11 Februari 1950.

Proposisi Muhammad Hatta tersebut juga dikuatkan oleh Prof.Dr. R Soepomo, dalam bukunya "Undang-Undang Sementara Republik Indonesia",1954 ketika menjelaskan bagian ke III Lambang dan Bahasa Negara dalam Konstitusi RIS 1949 Pasal 3:33

\section{Ichtisar Parlemen, 17 Februari 1950 nomor 2 memuat berita negara, bahwa sidang Dewan Menteri R.I.S tanggal 11 Februari 1950 telah mengesahkan Lambang Negara R.I.S yang direncanakan oleh Panitia Lambang Negara menurut bagian III pasal 3 Konstitusi R.I.S.Gambarnya lambang negara tersebut adalah dimuat dalam ichtisar Parlemen tersebut."}

Ketika disahkan lambang negara R.I.S tersebut, khususnya gambar bentuk kepala Rajawali Garuda Pancasila masih "gundul dan tidak berjambul" atau bentuk kepalanya belum seperti sekarang ini. Keterangan ini jugs diperkuat oleh A.G Pringgodigdo34 dalam Bukunya Sekitar Pancasila, yang diterbitkan oleh Departemen Pertahanan Keamanan, Pusat Sejarah ABRI, 1978: ${ }^{35}$

${ }^{31}$ Penetapan Lambang Negara, dinyatakan ditetapkan, Bhinneka Tunggal Ika ditetapkan oleh Kabinet RIS menjadi Lambang Negara, sebagaimana tertera pada Buku Lukisan Revolusi Indonesia 1945-1950, Kementrian Penerangan Republik Indonesia, hal. XXIII

${ }^{32}$ Z. Yasni, “Bung Hatta Menjawab”, (Jakarta: Gunung Agung, 1978), hal. 108.

33 Prof .Dr R.Soepomo, "Undang-Undang Dasar Sementara Republik Indonesia", (Jakarta :Noordhhof-kolff N.V, 1954), hal. 25.

${ }^{34}$ Prof. Mr. Abdoel Gaffar Pringgodigdo adalah mantan Menteri Kehakiman Indonesia dari tanggal 21 Januari sampai 6 September 1950, menggantikan Prof. Mr. Soepomo. 
Berdasarkan atas pasal 3 Konstitusi itu (RIS) pada tanggal 11 Februari 1950 Pemerintah RIS telah menetapkan lambang negara, yang berupa lukisan burung Garuda dan Perisai, yang terbagi dalam 5 ruang yang mengingatkan kepada PANCASILA. Pada waktu itu burung Garuda kepala "gundul", tidak pakai "jambul". Hal ini berubah dalam Lambang Negara Republik Indonesia Kesatuan, yang ditetapkan dengan Peraturan Pemerintah tanggal 17 Oktober 1951 No 66 Tahun 1951.

Pernyataan diatas juga diungkapkan oleh Sultan Hamid II dalam Transkripnya 15 April 1967:

Selandjutnya gambar lambang negara saja bisa diterima oleh anggota Panitia Lambang Negara, demikian djuga lambang negara rantjangan Mr Mohammad Jamin jang kemudian kami serahkan bersama kepada Perdana Menteri Mohammad Hatta, untuk dibawa ke Pemerintah dan sidang Parlemen RIS untuk dipilih. Alhamdulillah gambar rantjangan saja jang diterima, 10 Februari 1950 dan esoknja untuk pertama kali diperkenalkan kepada chalajak ramai di Hotel Des Indes, jang kemudian pada rapat Parlemen RIS bersama Pemerintah ditetapkan Parlemen RIS sebagai Lambang Negara RIS, pada tanggal 11 Februari 1950.

Walaupun demikian, ada masukan beberapa waktu kemudian dari Paduka Jang Mulia Presiden Soekarno ketika beliau sedang berpidato kenegaraan, 20 Februari 1950 melihat lambang negara tersebut jang tergantung di belakang podium Parleman Istana Merdeka Pedjambon, karena kepala burung Radjawali tidak 'berdjambul' dan terlihat 'gundul'. Paduka Jang Mulia meminta saja untuk memperbaiki bentuk kepala, kemudian saja mengubah bagian kepala mendjadi berdjambul, kemudian oleh Kementerian Penerangan RIS atas perintah Paduka Jang Mulia Presiden Soekarno kepada pelukis Dullah. ${ }^{36}$ untuk melukis kembali lambang negara tersebut.

Tanggal 15 Februari 1950 Presiden Soekarno memperkenalkan untuk pertama kalinya lambang negara tersebut kepada khalayak umum di Hotel Des Indes Jakarta, tanggal 17 Februari 1950 lambang negara disahkan oleh Dewan Menteri RIS dalam berita Parlamen RIS Nomor 2 dan pada tanggal 20 Februari $1950,{ }^{37}$ lambang negara yang dibuat Sultan

35 A.G Pringgodigdo, "SekitarPancasila", (Jakarta: Departemen Pertahanan Keamanan Pusat Sejarah ABRI, 1978), hal. 6.

\footnotetext{
${ }^{36}$ Dullah, adalah pelukis di Istana Kepresidenan selama Soekarno menjadi Presiden.

${ }^{37}$ Transkrip Sultan Hamid II, 15 Aril 1967, Op. Cit., hal. 8.
} 
Hamid II sudah terpasang didalam ruang sidang Parlemen RIS (sekarang Gedung Pancasila) Jakarta yang dibuka oleh Presiden Soekarno.

Gambar dimaksud diterangkan secara jelas dalam transkrip Sultan Hamid II, 15 April 1967 sebagai berikut: ${ }^{38}$

Selandjutnja gambar lambang negara saja bisa diterima oleh anggota Panitia Lambang Negara, demikian djuga lambang negara rantjangan Mr.M Yamin jang kemudian kami serahkan bersama kepada Perdana Menteri RIS Mohammad Hatta untuk dibawa ke Pemerintah dan sidang Parlemen RIS untuk dipilih, alhamdulillah gambar rantjangan saja jang diterima 10 Februari 1950 dan esoknja untuk pertama kali diperkenalkan kepada halajat ramai di Hotel Des Indes, jang kemudian pada rapat parlemen RIS bersama Pemerintah ditetapkan oleh Parlemen RIS sebagai Lambang Negara RIS pada tanggal 11 Februari 1950, walaupun demikian ada masukan beberapa waktu kemudian dari Paduka Jang Mulia Presiden Soekarno ketika beliau sedang berpidato kenegaraan 20 Februari 1950 melihat lambang negara tersebut jang tergantung dibelakang pondium di gedung parlemen Istana Merdeka Pedjambon, karena kepala burung Radjawalinja tidak "berjambul" dan terlihat "gundul.

\section{Penyempurnaan Lambang Negara}

Akhir Februari 1950 Sultan Hamid II mendapat saran dari Presiden Soekarno untuk menyempurnakan kembali pada bagian bentuk kepala burung Rajawali Garuda Pancasila yang terkesan "gundul" atau mirip elang bondol pada lambang negara Amerika Serikat. Selanjutnya sekitar awal Maret 1950 Sultan Hamid II mengajukan lukisan lambang negara yang sudah diperbaiki khususnya pada bagian kepala Rajawali-Garuda Pancasila.

Gambar tersebut ternyata masih mendapat masukan dari Presiden Soekarno, yaitu pada bagian bentuk cakar kaki yang mencengkram pita yang terlihat menghadap ke belakang terkesan terbalik. Penyempurnaan yang dilakukan Sultan Hamid II hanya tinggal merubah bentuk cakar kaki sehingga menghadap ke depan, dan bagian lain sudah sama seperti gambar lambang negara sekarang ini.

Mengenai gambar lambang negara inipun dijelaskan dalam transkrip Sultan Hamid II , 15 April 1967 sebagai berikut: ${ }^{39}$

Walapun saja harus susah pajah membuat sketsa kembali untuk pembentulan bagian tjakar kaki itu, tetapi saja

\footnotetext{
${ }^{38}$ Transkrip Sultan Hamid II, 15 April 1967, Ibid., hal. 4-5.

39 Ibid., hal. .5
} 
mengerti ini hal bagian jang sangat penting dalam lambang negara RIS, karena mengandung tiga konsep lambang sekaligus, jakni pertama, burung RadjawaliGaruda Pantja-Sila jang menurut perasaan bangsa Indonesia berdekatan dengan burung garuda dalam mitologi, kedua perisai idee Pantja-Sila ber"thawaf"/gilir balik, dan ketiga, seloka Bhinneka Tunggal Ika jang tertulis dalam pita warna putih, untuk itu saja meminta bantuan $R$ Ruhl untuk membuat sketsa dari lambang negara jang saja buat dengan membawa potret lukisan lambang negara jang dilukis oleh Dullah, karena lukisan Dullah jang gambar rantjangannja semula tjengkraman kakinja menghadap kebelakang telah diserahkan kepada kementerian penerangan RIS jang ketika itu masih berada di Yogjakarta, kemudian dimintakan kepada saja oleh Paduka Jang Mulia Presiden Soekarno untuk tidak disebarkan dahulu ke pelosok negara RIS, setelah itu sketsa transkrip/out werp jang dilukis R.Ruhl saja adjukan kembali ke Paduka Jang Mulia Presiden Soekarno, ternjata beliau langsung mendisposisi sebagai wapen negara, waktu itu tanggal 20 Maret 1950, kemudian beliau memerintahkan untuk memanggil Dullah sang pelukis Istana/pelukis kesayangan bung Karno untuk melukis kembali berdasarkan sketsa perbaikan R.Ruhl tersebut, walaupun ketika itu kita harus merugi beberapa ribu rupiah lagi untuk membajar pelukis Dullah.

Tanggal 20 Maret 1950 bentuk final gambar lambang negara rancangan Sultan Hamid II yang telah diperbaiki tersebut diajukan kepada Presiden Soekarno dan mendapat disposisi persetujuan presiden. Adapun isi disposisi tersebut berbunyi: ${ }^{40}$

J.M Sultan Hamid menteri negara, menurut pendapat saya lukisan Ruhl ini membuat lambang negara kita lebih kuat, maka untuk itu saya tetapkan bahwa ontwerp Ruhl inilah yang harus dipakai. Lebih baik kita rugi beberapa ribu rupiah daripada mempunyai lambang negara yang kurang sempurna. Saya harap J.M mengambil tindakan seperlunya contoh kehendak saya. Merdeka!.

Berdasarkan penjelasan dalam transkrip Sultan Hanmid II di atas dan bukti dokumen dalam penelitian ini, maka secara proses perancangan lambang negara Indonesia terjadi penyempurnaan secara

40 Disposisi Presiden Soekarno Kepada Sultan Hamid II, setelah sketsa Rancangan Lambang Negara Sultan Hamid II dikonsultasikan dengan Ruhl, seorang ahli Semiologi dari Perancis yang menjadi konsultan Sultan Hamid II dan Yamin ketika merancang gambar Lambang Negara, 1950. 
terus menerus sejak awal perancangannya sampai ditetapkan menjadi Lambang Negara, yaitu mulai dari rancangan tahap pertama yang mengambil figur burung garuda dalam mitologi bangsa Indonesia atau tahap pertama rancangan Sultan Hamid II sampai dengan rancangan tahap kedua yang mengambil figur burung Elang Rajawali yang lebih bersifat universal. Penyempurnaan dimaksud, yaitu mulai menghilangkan adanya tangan manusia yang memegang perisai Pancasil, perubahan bentuk kepala yang terkesan mitologis, kemudian berubah menjadi bentuk kepala burung Elang Rajawali yang terlihat "gundul" seperti mirip lambang negara Amerika Serikat, kemudian diberikan "jambul”.

Perubahan bentuk cakar kaki yang mencengkram pita berisi seloka Bhinneka Tunggal Ika yang semula menghadap kebelakang dan kemudian berubah menjadi kedepan, sehingga Dullah sang pelukis Istana kepercayaan Soekarno harus melukis empat kali hasil rancangan Lambang Negara dari Sultan Hamid II. Kemudian terakhir kalinya gambarnya dibuat skala ukuran oleh Sultan Hamid II dan gambar lambang negara ini kemudian menjadi lampiran Peraturan Pemerintah Nomor 66 Tahun 1951 berdasarkan Pasal $6 .^{41}$

Kemudian Presiden Soekarno setelah memberikan disposisi itu memerintahkan pelukis Istana bernama Dullah (1950-1960) untuk melukiskan kembali gambar tersebut sesuai bentuk final sebagaimana yang telah dibuat oleh Sultan Hamid II, atau seperti dipergunakan secara resmi sekarang ini dan patut pula ditambahkan, bahwa Dullah hanya melukis kembali sesuai skesta gambar lambang negara yang telah diperbaiki oleh Sultan Hamid II atau sebagaimana telah disposisi oleh Presiden Soekarno tanggal 20 Maret 1950.

Keterangan ini dapat dikemukakan dalam Majalah Gatra No 32 Tahun I, 25 Juni 1995, dalam judul "Bung Karno, Ikan dan Air", yang menyatakan: ${ }^{42}$

.... salah satu bentuk kepercayaan itu ialah permintaan bung Karno kepada Dullah untuk mengubah posisi kaki gambar Pancasila yang tadinya dirancang (penulis Sultan Hamid II) di Kementerian Penerangan. Dalam rancangan Kementerian Penerangan, kaki garuda dilukiskan seolah-olah menghadap ke belakang. Dan oleh Dullah dilukis kembali dengan membalik sehingga tampak menghadap kedepan....

41 Pasal 6 Peraturan Pemerintah Nomor 66 Tahun 1951: Bentuk warna dan Perbandingan ukuran Lambang Negara Republik Indonesia adalah sepereti terlukis dalam Lampiran pada Peraturan Pemerintah ini.

${ }^{42}$ Bung Karno, Ikan dan Air, ”Majalah Gatra”, Edisi No 32 Tahun I, 25 Juni 1995, hal. 51 dan lihat juga "Ensiklopedia Nasional Indonesia", (Jakarta: PT Cipta Adi Pustaka, 1989), hal. 65-66. 
Keterangan yang sama dinyatakan oleh Sultan Hamid II dalam transkripnya kepada Solichim Salam, 15 April 1967: ${ }^{43}$

Saja meminta bantuan D Ruhl Jr untuk membuat sketsa dari lambang negara jang saja buat dengan membawa potret lukisan lambang negara jang dilukis oleh Dullah, karena lukisan Dullah jang gambar rantjangannja semula tjengkraman kakinja menghadap kebelakang telah diserahkan kepada kementerian penerangan RIS jang ketika itu masih berada di Yogjakarta, kemudian dimintakan kepada saja oleh Paduka Jang Mulia Presiden Soekarno untuk tidak disebarkan dahulu ke pelosok negara RIS, setelah itu sketsa transkrip/out werp jang dilukis D.Ruhl Jr saja adjukan kembali ke Paduka Jang Mulia Presiden Soekarno, ternjata beliau langsung mendisposisi sebagai wapen negara, waktu itu tanggal 20 Maret 1950, kemudian beliau memerintahkan untuk memanggil Dullah sang pelukis Istana/pelukis kesayangan bung Karno untuk melukis kembali berdasarkan sketsa perbaikan R.Ruhl tersebut, walaupun ketika itu kita harus merugi beberapa ribu rupiah lagi untuk membajar pelukis Dullah.

Hasil lukisan Dullah itulah jang kemudian oleh Paduka Jang Mulia Presiden Soekarno diperintahkan kepada kementerian penerangan untuk disebarkan luaskan ke seluruh pelosok negara RIS jang ketika itu saja lihat banjak warga bangsa memasang di rumah-rumah.

Berdasarkan disposisi Presiden Soekarno (20 Maret 1950), untuk terakhir kalinya Sultan Hamid II menyelesaikan penyempurnaan bentuk final lambang negara, yaitu dengan menambahkan skala ukuran dan tata warna gambar lambang negara (lukisan otentiknya sudah diserahkan kepada Mas Agung, Yayasan Idayu Jakarta)

\section{Pengaturan Lambang Negara Dalam Peraturan Perundang- Undangan}

Tanggal 10 Juli 1951 Dewan Menteri mengadakan rapat mengenai pengaturan lambang negara, yaitu rancangan Peraturan Pemerintah yang mengatur lambang negara berdasarkan Pasal 3 ayat 3 Undang-Undang Dasar Sementara 1950. Tanggal 17 Agustus 1951 lambang negara dimasyarakatkan pemakaiannya diseluruh negara kesatuan Republik Indonesia dan gambarnya disebar-luaskan keseluruh pelosok tanah air.

Tanggal 17 Agustus 1951 Presiden Soekarno dan Perdana Menteri Sukiman Wirjosandjoyo menetapkan Peraturan Pemerintah No 66 tahun 1951 tentang Lambang Negara, pada pasal 2, 3 ditetapkan, bahwa warna, perbandingan ukuran dan bentuk lambang negara adalah seperti

43 Transkrip Sultan Hamid II kepada Solichim Salam, 15 April 1967, hal. 6. 
ditentukan dalam Pasal 6, yaitu seperti terlampir dalam Peraturan Pemerintah tersebut.

Tanggal 28 November 1951 Peraturan Pemerintah No 66 tahun 1951 diundangkan oleh Menteri Kehakimaan: M. Nasroen dalam Lembaran Negara No 111 dan penjelasannya dalam Tambahan Lembaran Negara No 176 tahun 1951. Sejak saat itu secara yuridis formal gambar lambang negara rancangan Sultan Hamid II seperti terlampir dalam Peraturan Pemeritah No 66 Tahun 1951 secara resmi menjadi lambang negara kesatuan republik Indonesia.

Tanggal 30 Mei 1958 Dewan Menteri mengadakan rapat yang ke 107 mengenai rancangan Peraturan Pemerintah tentang Penggunaan Lambang Negara. Tanggal 5 Juni 1958 Muhammad Yamin dalam kapasitas sebagai mantan Panitia Lambang Negara, dalam suatu kesempatan Pidato di Istana Negara yang dihadiri para Menteri serta Dewan Nasional menjelaskan arti dan makna simbol-simbol dalam perisai Pancasila pada lambang negara yang dirancang Sultan Hamid II.

Tanggal 26 Juni 1958 Presiden Republik Indonesia Soekarno dan Perdana Menteri Juanda menetapkan Peraturan Pemeritahan No 43 Tahun 1958 Tentang penggunaan lambang negara diundangkan oleh menteri Kehakiman: G.A. Maengkom pada Lembaran Negara No 71 Tahun 1958 dan penjelasannya dalam Tambahan Lembaran Negara No 1636 Tahun 1958.

Pada tanggal 22 Juli 1958 Presiden Soekarno memberikan pidato yang berkaitan dengan lambang negara di Istana Negara yang intinya antara lain kegagahan Burung Rajawali Garuda Pancasila, dan kaitannya lambang negara dengan dasar negara Pancasila. Adapun isi selengkapnya pidato tersebut sebagai berikut: ${ }^{44}$

Saudara-saudara, lihatlah Lambang Negara kita di belakang ini, alangkah megahnya, alangkah hebat dan cantiknya.

Burung Elang Rajawali, garuda yang sayap kanan dan sayap kirinya berelar 17 buah, dengan ekor yang berelar 8 buah, tanggal 17 bulan 8, dan yang berkalungkan perisai yang di atas perisai itu tergambar Pancasila. Yang di bawahnya tertulis seloka buatan Empu Tantular "Bhinneka Tunggal Ika", Bhina Ika Tunggal Ika, Berjenis-jenis tetapi tunggal.

Pancasila yang tergambar di pusat bintang cermelang atas dasar hitam, sinar cermerlang abadi dari pada Ketuhanan Yang Maha Esa, pohon beringin lambang kebangsaan. Rantai yang terdiri dari pada gelang-gelangan dan persegi dan bundar yang bersambung satu sama lain dalam sambungan yang tiada putusnya, peri kemanusiaan.

${ }^{44}$ Pidato Presiden Soekarno 22 Juli 1958 , Arsip Nasional, 1999. 
Banteng Indonesia lambang kedaulatan rakyat. Kapas dan padi lambang kecukupan sandang-pangan, keadilan sosial.

Lihatlah sekali lagi, aku berkata indahnya Lambang Negara ini, yang menurut pendapat saya Lambang Negara Republik Indonesia ini adalah yang terindah dan terhebat dari pada seluruh lambang-lambang Negara di muka bumi ini. Saya telah melihat dan mempelajari lambang-lambang negara yang lain-lain. Tapi tidak ada satu yang sehebat, seharmonis seperti Lambang Negara Republik Indonesia. Lambang yang telah dicintai oleh rakyat kita sehingga jikalau kita masuk ke desadesa sampai kepelosok-pelosok yang paling jauh dari dunian ramai, lambang ini sering dicoretkan orang di gardu-gardu, di tembok-tembok, di gerbang-gerbang, yang orang dirikan dikalau hendak menyatakan suatu ucapan selamat datang kepada seorang tamu.

Lambang yang demikian telah terpaku di dalamnya kalbu Rakyat Indonesia, sehingga lambang ini telah menjadi darah daging rakyat Indonesia dalam kecintaannya kepada Republik, sehingga bencana batin akan amat besarlah jikalau dasar negara kita itu dirobah, jikalau Dasar Negara itu tidak ditetapkan dan dilangengkan: Pancasila. Sebab lambang negara sekarang yang telah dicintai oleh Rakyat Indonesia sampai ke pelosok-pelosok desa itu adalah lambang yang bersendikan kepada Pancasila. Sesuatu perobahan dari Dasar Negara membawa perobahan dari pada lambang negara.

Saya mengetahui bahwa jikalau lambang negara ini dirobah, sebagian terbesar dari pada Rakyat Indonesia akan menolaknya. Cinta rakyat Indonesia kepada lambang ini telah terpaku sedalam-dalamnya di dalam jiwanya, berarti cinta sebagian terbesar dari pada Rakyat Indonesia kepada Pancasila. Lihatlah sekali lagi kepada Lambang Negara kita Pancasila, yang dilukiskan diatas burung garuda.

Berdasarkan Pidato Presiden Soekarno di atas memberikan penegasan, bahwa ada korelasi antara lambang negara dengan Pancasila, karena menurut Soekarno Lambang Negara tersebut adalah lambang yang bersendikan kepada Pancasila. Beliau menyatakan, bahwa sesuatu perobahan dari dasar negara membawa perubahan dari Lambang Negara.

\section{Mengapa Sejarah Hukum Lambang Negara Selama ini "Tersembunyi"?}

Berdasarkan kronologis sejarah hukum perancangan Lambang Negara di atas Nanang Hidayat, dalam bukunya yang berjudul "Mencari Telur Garuda," menyatakan: 
Bila berpedoman pada tesis Turiman, 1999 maka hingga 2008 berarti 57 tahun kemudian setelah ditetapkan Garuda Pancasila sebagai Lambang Negara 17 Agustus 1951 (Penulis Peraturan Pemerintah Nomor 66 Tahun 1951) atau 11 Februari 1950 di Jakarta, baru ditemukan secara akademik bahwa Sultan Hamid II-lah penciptanya. Waktu yang cukup lama bagi sebuah bangsa untuk mendiamkan terpendamnya bagian sejarah yang teramat penting. Cukup lama bagi sebuah bangsa yang bercita-cita rakyatnya menjadi Pancasilais sejati, untuk bungkam tentang siapa perancangnya. $^{45}$

Mengapa demikian? Hal ini dikarenakan di kalangan publik dan berbagai pelatihan Pedoman Penghayatan dan Pengamalan Pancasila $(\mathrm{P} 4)^{46}$ yang dilaksanakan oleh Pemerintah Orde Baru berkembang pendapat atau dugaan publik yang membuat lambang negara adalah Muhammad Yamin, sedangkan menurut Mohammad Hatta pada tahun 1978 telah menyatakan, bahwa yang membuat atau merancang adalah Sultan Hamid II dari Pontianak, oleh karena itu sejak penerbitkan buku Bung Hatta Menjawab terbitlah berbagai tulisan yang membenarkan

\footnotetext{
${ }^{45}$ Nanang Hidayat, "Mencari Telur Garuda”, (Jakarta: Nalar, tt), hal. 30.
}

46 Pemerintah melalui MPR mencabut TAP MPR II/MPR/1978 tentang Pedoman Penghayatan dan Pengamalan Pancasila (Eka Prasetya Pacakarsa) dan menggantikannya dengan mengeluarkan TAP MPR XVIII/MPR/1998. Jika menelusuri sejarah bangsa Indonesia merefleksikan bagaimana Presiden Soekarno sendiri bahkan langsung memberikan kursuskurusus Pancasila bagi para pejabat pemerintah dan mahasiswa kala itu, kemudian Pak Harto mengajarkan hal serupa melalui Penataran P4. Kendati terdapat perbedaan cara, mereka adalah orang yang betul-betul menjaga Pancasila.Kegiatan Penataran P4, baik pola 25, 45 maupun 100 jam yang dilaksanakan di era itu bertujuan memasyarakatkan Pancasila secara baik, dan mengamalkannya dalam kehidupan bermasyarakat, berbangsa dan bernegara. Sila demi sila dikupas dan diuraikan dalam butir-butir yang kemudian dikembangkan lagi menjadi 45 butir.Penghapusan Penataran P4 pasti tidak akan dilakukan saat itu. Terbukti di era reformasi telah menjadikan pikiran bangsa Indonesia lebih liberalis dan salah jalan. Muncul tirani mayoritas, anarkisme, hedonisme, kapitalisme dan pelunturan kepribadian luhur bangsa Indonesia.Keanehan terjadi ketika pemerintah bersama DPR membuat Undang-Undang No. 27 Tahun 2009 dengan malu-malu ingin memperbaiki kecerobohan itu, memasyarakatkan empat pilar utama negara yang terdiri dari Pancasila, UUD 1945, NKRI dan Bhinneka Tunggal Ika. Bukankah kebijakan itu selaras dengan latar belakang timbul Penataran Pedoman Penghayatan Pengamalan Pancasila yang disampaikan pada acara Dies Natalies ke-25 Universitas Gajah Mada di Yogyakarta tanggal 19 Desember 1974, Presiden Soeharto menyatakan keperihatinanya bahwa Pancasila baru sekedar dimiliki belum dihayati. Pada tanggal 12 April 1976, Presiden Suharto mengemukakan gagasan mengenai pedoman untuk menghayati dan mengamalkan Pancasila yaitu gagasan Ekaprasetia Pancakarsa. Gagasan tersebut selanjutnya ditetapkan sebagai Ketetapan MPR dalam sidang umum tahun 1978 mengenai "Pedoman Penghayatan dan Pengamalan Pancasila" atau biasa dikenal sebagai P4. Adanya penataran P4 (Pedoman Penghayatan dan Pengamalan Pancasila) sebagai gerakan budaya yang ditujukan untuk membentuk manusia Pancasila, yang kemudian dikuatkan dengan ketetapan MPR No II/MPR/1978. 
pernyataan Mohammad Hatta, seperti, ${ }^{47}$ investigasi Majalah Tempo, 3 Maret 1979, Garuda Pancasila Siapa Penciptanya, Majalah Intisari No 205 Tahun 1980 Agustus, dengan judul: Kapan Lahirnya Garuda Pancasila ? Muclich Jasin, FH UGM, 1981 Siapakah Pencipta Garuda Pancasila, yang pada akhir Tahun 1986 terbit buku Akmal Sutja berjudul: "Sekitar Garuda Pancasila" beliau menyatakan, bahwa membenarkan pendapat Mohammad Hatta yang menyatakan, bahwa yang merancang gambar lambang negara adalah Sultan Hamid II, sampai dengan adanya penelitian lebih lanjut. Isi selengkapnya pernyataan itu adalah: ${ }^{48}$

...sampai sampai ada penelitian yang dapat dipercaya mengenai hal ini, kiranya dapat diterima saja keterangan dari Bung Hatta, bahwa Sultan Hamid II yang telah mendapat ilham brilian untuk mengangkat kembali simbol-simbol asli bangsa Indonesia yang telah dimuliakan oleh Bangsa Indonesia sepanjang sejarahnya. Karena Bung Hatta salah seorang pemimpin yang cukup terpercaya yang saat itu menjadi wakil Presiden, membenarkan pendapat ini, ketimbang praduga berdasarkan atas latar belakang Muhammad Yamin saja.

Pertanyaannya mengapa sampai berkembang di masyarakat dugaan kepada Muhammad Yamin yang membuat gambar Lambang Negara? Akmal Sutja dalam bukunya sekitar Garuda Pancasila, 1986 sebagai berikut: ${ }^{49}$

Dugaan yang sangat populer dan bahkan banyak orang menyakini, bahwa pencipta Lambang Negara Garuda Pancasila itu adalah Muhammad Yamin. Dugaan Yamin sebagai pencipta lambang negara ini diperkuat oleh:

1. Muhammad Yamin adalah seorang sejarahwan, mempunyai minat yang besar pula terhadap sejarah kebudayaan Indonesia ini perkuat dugaan orang bahwa minat ilmunya yang dalam tentang sejarah Indonesia, la akan lebih mengenal peradaban Bangsa Indonesia yang berhubungan dengan garuda seperti,

${ }^{47}$ Berbagai Tulisan tersebut, dikliping oleh Soenaryo, Ketua BP 7 Pusat sejak 1978 sampai dengan 1997 kemudian dibuku dengan judul Bhinneka Tunggal Ika, BP 7 Pusat, Jakarta. Dalam kata Pengantarnya Soernayo menyatakan: "Buku Bung Hatta menjawab" telah membuka mata para nara sumber Penataran P4 untuk meluruskan sejarah tentang perancangan lambang negara yang menyatakan Mr.M. Yamin yang hanya didasarkan pada dugaan saja, sedang Mohammat Hatta pada waktu itu adalah perdana menerti RIS lebih menyatakan secara jujur, bahwa yang merancang gambar lambang negara adalah Sultan Hamid II dari Pontianak dalam kedudukan sebagai Menteri Negara zonder FortoFolio RIS-1949-1950.

\footnotetext{
${ }^{48}$ Akmal Sutja, "Sekitar Garuda Pancasila", (Bandung: Angkasa, 1986), hal. 78-79.

${ }^{49}$ Ibid., hal. 6-77.
} 
banyak terpahat padA candi-candi dari abad XVII sampai abad XVI. Yamin sendiri berminat sekali untuk meneliti candi-candi tersebut, sehingga tidak mengherankan, dengan banyaknya lukisan Garuda padA berbagai candi menimbulkan ilham bagi Muhammad Yamin untuk mengangkat garuda simbol kenegaraan kita. Dimana dia sendiri jugs menjadi ketua Panitia Lencana Negara, sehingga membuka kesempatan yang luas baginya untuk berperan dalam menentukan rancangan lambang negara.

2. Di samping Muhammad Yamin seorang sejarahwan yang mengenal lukisan garuda pada berbagai candi-candi tersebut, sudah barang tentu pula mengenal kesusasteraan atau mitologi lama yang memuat dan menokohkan garuda seperti dalam kitab Mahabarata di atas. Dan selaku putra Talawi, Sumatra Barat, Ka Rambun Pamenan yang sering diangkat menjadi "randai" itu sudah dapat disepakati Yamin secara dekat atau paling kurang pernah diceritakan orang ketika ia masih belia.

3. Walaupun Muhammad Yamin tidak menyebutkan seberapa jauh peranannya dalam merancang lambang negara Garuda Pancasila ini, tetapi dalam berbagai kesempatan ia sering memberikan keterangan tentang Garuda Pancasila secara baik dengan mengemukakan berbagai fakta sejarah. Seperti dalam pidato 5 Juni 1958 di lstana Negara yang dihadiri oleh Presiden, pari Menteri dan Dewan Nasional. Dalam pidato memperingati lahirnya Pancasila (baca istilah Pancasila) ia mengambil waktu untuk menguraikan perihal Garuda Pancasila yang diakuinya sendiri sedikit penyimpangan dari judul pidatonya. Setelah menguraikan Garuda Pancasila: dengan demikian kata Muhammad Yamin, maka kini saya merasa lega, karena saya mendapat kesempatan untuk memberikan keterangan sedikit tentang Garuda Pancasila dalam perayaan yang meriah ini. Ini menjadi kuat dugaan orang, bahwa Muhammad Yamin adalah penciptanya karena informasi tentang lambang negara berada di dalam ingatan Muhammad Yamin terus menerus. Bahkan dalam buku 6000 Tahun Sang Merah Putih terbit tahun 1954, yakni 3 tahun setelah Garuda Pancasila ditetapkan secara resmi menjadi lambang negara Indonesia, ia banyak menguraikan perihal Garuda dalam buku tersebut.

Ketiga alasan yang dikemukakan Akmal Sutja di atas itulah yang sering menimbulkan anggapan sebagian orang, bahwa gambar lambang negara sekarang ini adalah Karya Muhammad Yamin, karena berdasarkan atas latar belakang Muhammad Yamin sebagai seorang sejarahwan atau berdasar karena ia pernah pidato pada tanggal 5 Juni 1958 tentang Garuda Pancasila dan keterangan tentang Garuda Pancasila di bukunya 6000 Tahun Sang Merah Putih. Tetapi perlu dicatat pula, 
bahwa Akmal Sutja dalam buku yang sama (Sekitar Garuda Pancasila) tersebut menyatakan: ${ }^{50}$

Tetapi tidak bisa dipungkiri adanya kemungkinan lain, karena tidak ada petunjuk yang menjelaskan orang yang merancang lambang negara ini secara tegas, di samping Muhammad Yamin mungkin saja ada orang lain, tapi tidak mau disebutkan namanya, atau karena yang merancang lambang negara adalah tugas yang dibebankan kepada sebuah Panitia, maka hasil rancangannya diserahkan saja sebagai hasil kerja Panitia. Boleh jadi ada seorang perancang atau mereka terlibat bersama-sama.

Dugaan bahwa perancang lambang negara tidak dibuat oleh seseorang, tetapi melibatkan beberapa orang dalam Panitia Lencana Negara merupakan dugaan yang mendekati kebenaran, Karena kalau kita perhatikan beberapa rancangan lambang negara koleksi Muhammad Yamin dan Sultan Hamid di gedung Kebangkitan Nasional (sekarang berada di Yayasan ldayu) Jakarta, memberikan petunjuk yang menyakinkan bahwa lambang negara kita itu mendapat penyempurnaan terus-menerus sebelum ditetapkan menjadi lambang negara resmi, sehingga kita temukan suatu rancangan mirip dengan rancangan lainnya.

Perlu dikemukakan, bahwa didalam Ensiklopedia Nasional Indonesia tidak ditegaskan secara tegas tentang siapa perancang lambang negara hanya disebutkan sebagai berikut: ${ }^{51}$

Cikal bakal Garuda berawal ketika Muhammad Yamin menjadi Ketua Panitia Lencana Negara dengan anggota antara lain Sultan Hamid II, yang pada waktu itu menjabat Menteri Negara dalam Kabinet Republik Indonesia Serikat. Atas permintaan mereka dibuat beberapa lambang. Sebagian rencana gambar dan skesta lambang garuda dan lambang lain, yang menjadi cikal bakal lambang negara Republik Indonesia, kini masih tersimpan dengan balk. Sebuah rancangan menokohkan figur garuda dan agak mirip dengan lambang negara kita di dalam lingkaran sebelah atas tertulis dengan huruf latin perkataan Republik Indonesia Serikat. Burung garuda berdiri di atas sebuah bantalan bunga teratai (Padma). Kepala garuda digambarkan menurut

${ }^{50}$ Ibid., hal. 79.

51 "Ensiklopedia Nasional Indonesia", Jilid 17 (Jakarta: PT. Cipta Adi Pustaka, 1989), hal. 365-366, atau lihat "Ensiklopedia Indonesia Edisi Khusus", Aid 7 (Jakarta: Ichtiar Baru-Van Hoeve, 1986), hal. 3970. 
contoh klasik dari candi-candi atau pahatan lain, kepala burung dengan rambut ikal, tangan garuda memegang perisai yang terbagi menjadi empat bidang. Di tengah perisai ada garis melintang yang menggambarkan khatulistiwa. Pada perisai, bidang kesatu, terlihat gambar banteng (lambang kekuatan, keberanian,dan keuletan) yang ke-2 (menurut arah jarum jam) pohon beringin (kekuataan hidup), ke-3 batang padi (lambang kemakmuran) dan ke-4 keris (lambang keadilan). Rancangan lain juga berbentuk bulat dengan garuda di atas bantalan teratai, hanya tak tampak jelas bahwa perisai itu dicengkram garuda sebab cengkramannya hanya sedikit menyembul di atas perisai. Garuda memakai mahkota, kalung dan anting-anting, sayap ke bawah, di tengah perisai terbagi empat bagian, dan di tengahnya masih ada tambahan satu perisai kecil bergambar banteng. Gambar dalam perisai adalah batang padi, pohon beringin, dan keris. Tulisan huruf Arab Melayu: berbunyi Republik Indonesia Serikat.

Jika mendasarkan keterangan Eksiklopedia Nasional Indonesia tersebut di atas, keterangan ini lebih merujuk kepada skesta awal lambang negara yang dibuat oleh Menteri Negara Sultan Hamid II berdasarkan dokumen yang diserahkan kepada H. Mas Agung 18 Juli 1974 dan ini semakin memperkuat, bahwa Sultan Hamid II sewaktu menjabat Menteri Negara tidak ada tugas lain yang dipercayakan oleh Presiden Soekarno selain membuat rencana lambang negara, seperti dinyatakan secara tegas oleh Sultan Hamid II dalam pleidoi yang dibacakan Sultan Hamid II pada Sidang Mahkamah Agung24) tanggal 23 Maret $1953:^{52}$

Apakah yang harus kerjakan? Tindakan apa yang saya dapat ambil? Sebagai Menteri Negara saya hanya diserahi tugas menyiapkan Gedung Parlemen dan membikin rencana buat lambang negara. Sampai saya ditangkap (5 April 1950) dan kemudian ditahan tak ada tugas lain tugas saya!

Penegasan siapa perancang lambang negara yang bentuk gambar sekarang ini adalah sebagaimana keterangan Mohammad Hatta itu selengkapnya adalah: ${ }^{53}$

.... Patut pula ditambahkan sebagai catatan bahwa lambang dengan tulisan yang mempunyai arti yang demikian mendalam itu, dipadukan menjadi seperti sekarang ini, dengan melalui sayembara waktu RIS dulu dan dilaksanakan oleh Menteri

\footnotetext{
52 "Buku Proses Peristiwa Sultan Hamid II", Op. Cit., hal. 176.

53 "Bung Hatta Menjawab", Op. Cit., hal. 108.
} 
Priono, Banyak gambar yang masuk waktu itu, tetapi yang terbaik akhirnya ada dua buah, satu dari Muhammad Yamin dan yang satu lagi dari Sultan Hamid. Yang diterima oleh Pemerintah dan DPR adalah dari Sultan Hamid yakni seperti sekarang ini. Adapun dari Muhammad Yamin ditolak, karena disana ada gambar sinar-sinar matahari dan menampakan sedikit banyak disengaja atau tidak pengaruh Jepang. Saya berpendapat bahwa apa yang ada sekarang itu, seperti uraian saya tadi sudah tepat dan bernilai abadi bagi kehidupan negara dan bangsa Indonesia.

Pada bagian lain buku Bung Hatta Menjawab: ${ }^{54}$

Semboyan Bhinneka' Tunggal Ika adalah ciptaan Bung Karno, setelah kita merdeka, semboyan itu kemudian diperkuat dengan lambang yang dibuat oleh Sultan Abdul Hamid Pontianak dan diresmikan pemakaiannya oleh Kabinet RIS tanggal 11 Februari 1950.

Proposisi Muhammad Hatta tersebut juga dikuatkan oleh Prof.Dr. R Soepomo, dalam bukunya "Undang-Undang Sementara Republik Indonesia", 1954 ketika menjelaskan bagian ke III Lambang dan Bahasa Negara dalam Konstitusi RIS 1949 Pasal $3:^{.55}$

Ichtisar Parlemen, 17 Februari 1950 nomor 2 memuat berita negara, bahwa sidang Dewan Menteri R.I.S tanggal 11 Februari 1950 telah mengesahkan Lambang Negara R.I.S yang direncanakan oleh Panitia Lambang Negara menurut bagian III pasal 3 Konstitusi R.I.S. Gambarnya lambang negara tersebut adalah dimuat dalam ichtisar Parlemen tersebut."

Demikian tulisan hasil penelitian ini terinspirasi dari Buku berjudul "Sekitar Garuda Pancasila" yang ditulis oleh Akmal Sutja, 1986 pada halaman 79 beliau menyatakan, bahwa membenarkan pendapat Mohammad Hatta yang menyatakan, bahwa yang merancang gambar lambang negara adalah Sultan Hamid II, sampai dengan adanya penelitian lebih lanjut. Isi selengkapnya pernyataan itu adalah: ${ }^{56}$

Sampai ada penelitian yang dapat dipercaya mengenai hal ini, kiranya dapat diterima saja keterangan dari Bung Hatta, bahwa Sultan Hamid II yang telah mendapat ilham brilian untuk mengangkat kembali simbol-simbol asli bangsa Indonesia yang telah dimuliakan oleh Bangsa Indonesia

${ }^{54}$ Z. Yasni, Op. Cit., hal. 108.

${ }^{55}$ Prof .Dr R.Soepomo, Undang-Undang Dasar Sementara Republik Indonesia, (Jakarta: Noordhhof-kolff N.V, 1954), hal. 25.

${ }^{56}$ Akmal Sutja, Op. Cit., hal. 78-79. 
sepanjang sejarahnya. Karena Bung Hatta salah seorang pemimpin yang cukup terpercaya yang saat itu menjadi wakil Presiden,(Penulis Perdana Menteri RIS, 1950) membenarkan pendapat ini, ketimbang praduga berdasarkan atas latar belakang Muhammad Yamin saja.

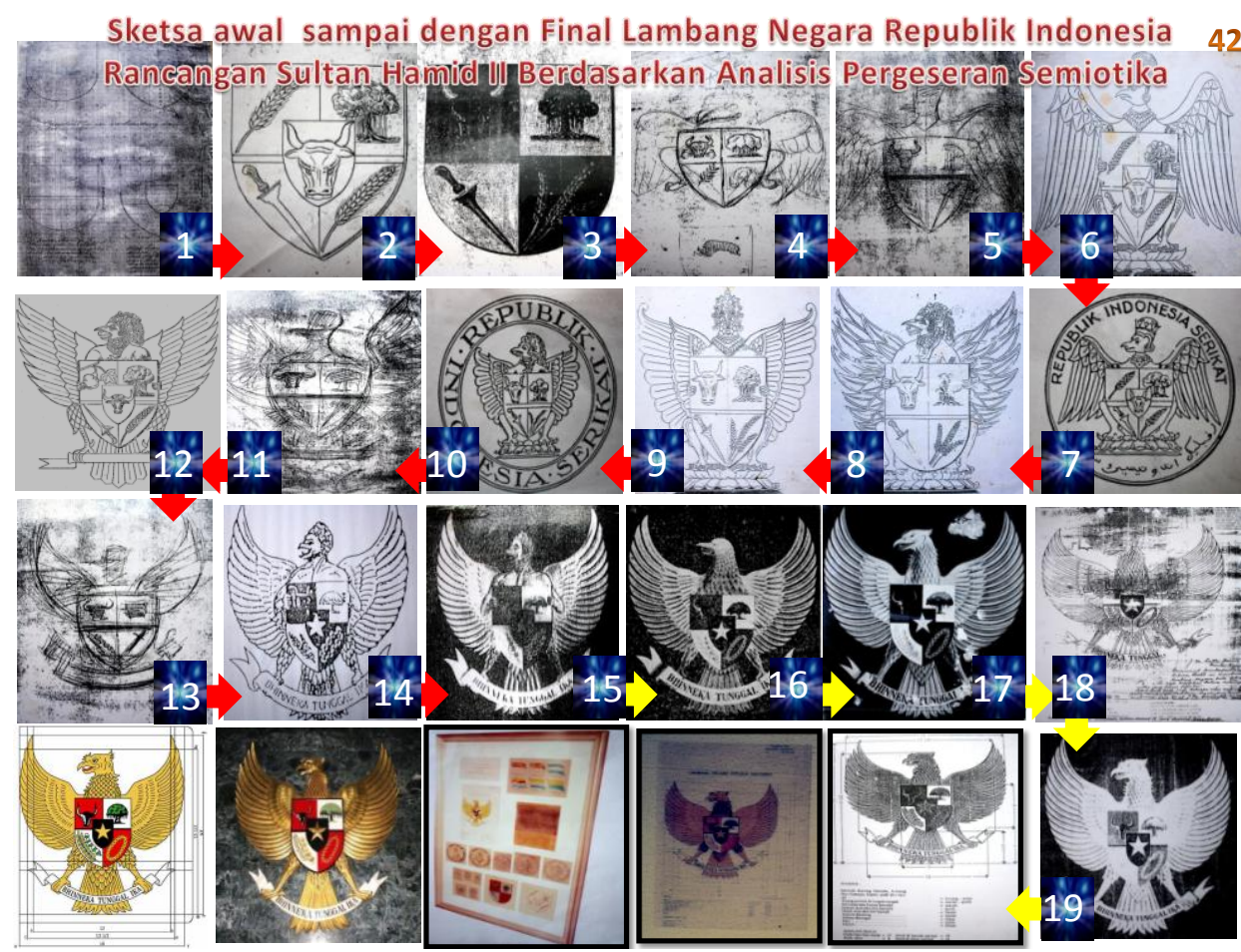

\section{8. Penutup}

Sebagai penutup patut dipaparkan, bahwa perjuangan untuk mendapat pengakuan secara de facto, dan de jure beberapa pihak telah mengambil bagian dalam sosialisasi sejarah hukum perancangan lambang negara Republik Indonesia, sebagaimana paparan berikut ini.

Alasan politik cukup lama Sultan Hamid II tidak diakui sebagai perancang Lambang Negara. Pengakuan resmi Pemerintah Republik Indonesia terhadap karya Sultan Hamid II sebagai Perancang Lambang Negara Garuda Pancasila, ditandai dengan langkah Kementerian Luar Negeri Republik Indonesia dan Museum Konferensi Asia Afrika, di Bandung, Provinsi Jawa Barat, menerbitkan buku kecil berwarna, ukuran 11 centimeter x 20 centimeter, setebal 48 halaman di awal tahun 2012. Di dalam buku saku itu, disebutkan dari berbagai rancangan yang dibuat, rancangan dibuat oleh Sultan Hamid II yang dipilih Presiden Soekarno sebagai Lambang Negara yang kemudian dikenal dengan Garuda Pancasila. 


\section{Daftar Pustakaan}

\section{Buku}

Adam, Aswi Warman. Menguak Misteri Sejarah, Jakarta: Kompas Press, Juli 2010.

BP 7 Pusat, Kumpulan Peraturan Pemerintah Tentang: Lambang Negara, Bendera Kebangsaan, Lagu Kebangsaan Indonesia Raya, Jakarta, 1994.

Daruni, Endang Asdi. Lambang Negara Republik Garuda Pancasila: DP Lukman, Yogyakarta, 1980.

Hidayat, Nanang R. Mencari Telur Garuda, Jakarta: Nalar, 2008.

Persaja. Proses Peristiwa Sultan Hamid II, Jakarta: Persaja-Percetakan Express, 1953.

Pringgodigdo, A.G. Sekitar Pancasila, Jakarta: Departemen Pertahanan Keamanan. Pusat Sejarah ABRI, 1978.

Pringgodigdo. H.A.K. Tiga Undang-Undang Dasar, Jakarta: PT Pembangunan,1974.

Yamin, Muhammad. Naskah Persiapan Undang-Undang Dasar 1945, Jilid I Cetakan Kedua, Jakarta, Prapanca, 1967

Naskah Persiapan Undang-Undang Dasar 1945. Jilid

Kedua, Cet II, Jakarta :Siguntang, 1971. , 6000 Tahun Sang Merah Putih, Siguntang, 1954.

Prapanca 1967.

Sutja, Akmal. Sekitar Garuda Pancasila, Bandung: Angkasa, 1986.

Yasni, Z. Bung Hatta Menjawab, Jakarta: Gunung Agung, Cet. Ketiga, 1980

\section{Tesis}

Turiman, "Sejarah Hukum Lambang Negara Republik Indonesia", Tesis, Program Pasca Sarjana Ilmu Hukum, UI, Jakarta, 1999.

\section{Makalah}

Turiman. "Lambang Negara Suatu Deskripsi Analisis Dari Sudut Pandang Hukum Dan Kehidupan Kenegaraan”. Makalah Diskusi Terbatas Dalam Program Pasca Sarjana Magiste Ilmu Hukum , U1 Tahun 1995. 


\section{Artikel}

Agastia, "Enam Ratus Tahun Bhinneka Tunggal Ika", Mimbar BP 7 Pusat, No 17 Tahun 111, 1988.

Azyumardi Azra, "Rejuvenasi" Pancasila dan Kepemimpinan Nasional", Kompas. 17 Juni 2004.

Dimyati Hartono, "Dinamisasi Stabilitas Nasional”, Suara Pembaharuan, Kamis, 30 Mei 1996.

Faizal, Mindra Iskandar. "Garuda Pancasila Sejak Abad-Abad Yang Silam”, Suara Karya, 21 April 1986.

Hutabarat, M.H. "Arti dan penggunaan Burung Garuda Sebagai Lambang Negara”, Mimbar BP 7 Pusat No.7 Tahun II, 1982.

Jasin, Muslich. "Siapakah Pencipta Garuda Pancasila?”, Berita Buana, 13 Agustus 1981.

Kompas, 30 desember 2002.

Kuntowijoyo. "Pancasila: Antara Mitos dan Ideologi", Majalah Umat No. 3 Tahun 11/5 Agustus 1996.

Norma, Moh. "Selamatkan Sang Elang”, Majalah Titian, No. 27, 1978.

Priyanto, Yusuf Eddy. "Tanda dan Simbol Dalam Kehidupan Manusia", Lontar Majalah Universitas Hasanundin, No 17 Tahun Ke XXII, 1983.

Wahyono, M. “Sang Garuda”, Majalah Intisari No 141, 1971.

Setiadijaya, Barlan. "Dalam Lambang Negara Mengapa Menengok Kekanan? Garuda Pancasila Jenis Burung Betina", Suara Pembaharuan, 2 Juni 1987.

Setianegara, lnsan. "Bhinneka Tunggal Ika", Harian pelita, 18 April 1981.

Slamet, Ki Sakti. "Salah Satu Pengertian Terhadap Arti Ika”, Mimbar BP 7 Pusat, No. 15 Tahun II, 1985.

Soekarno. "Tetap Terbanglah, Rajawali”, Pidato P.J.M Presiders Republik Indonesia pada Tanggal 17 Agustus 1955.

Solichin Salam, "Lambang Negara, Sejarah dan Perancangnya", Berita Buana, 17 Oktober 1996.

Sunaryo. G. "Proses Terbentuknya Lambang Negara”, Forum Keadilan, No. 19 Mei 1991.

"Dari Bhinneka Tunggal Ika Sampai Garuda Pancasila”, (Kumpulan Clipings), Jakarta, 1987.

Pancasila", Merdeka, 12 Desember 1983. 
Sunyoto, Agus. "Garuda Sebagai Lambang Pengabdian Dan Pembebasan", Mimbar BP 7 Pusat, No. 15 Tahun III, 1985.

Suwito, Santoro. "Bhinneka Tunggal Ika Didalam Boddakwaya Sutasoma", Tanggal 20 Mei 1970.

Wibisono, Koento. ”Radikalisasi Pancasila”, Kompas, 20 Februari 2001.

”Bung Karno, Ikan Dan Air", Gatra No.32 Tahun I, 24 Juni 1995.

"Garuda Pancasila Siapa Penciptanya" Agustus 1980. "Elang-Elang Lambang Negara”, Majalah Intisari. No. 205 Mei 1999.

"Siapa Perancang Garuda Pancasila", Mimbar UNTAN, Edisi No 11 \& 12 Tahun XV, Universitas Tanjungpura Pontianak, Kal-Bar, 1999.

"Kalau Memang Sultan Hamid Kenapa Takut",. Mimbar Untan, Edisi No 11 \& 12 Tahun ke X Universitas Tanjungpura Pontianak, Kal-Bar, 1994.

"Garuda Pancasila, Siapa Penciptanya”, Tempo, 3 Maret 1979

“Arti Sebuah Simbol”, Warta Windudarma, No. 224, 224.

\section{Ensiklopedia}

Ensiklopedia Indonesia Edisi Khusus, Jakarta: PT Ichtiar Van Hoeve, 1986.

Ensiklopedia Pancasila, 1994.

\section{Peraturan Perundangan}

Konstitusi Republik Indonesia Serikat (RIS) 1949.

Undang-Undang Dasar Sementara Republik Indonesia, 1950.

Undang-Undang Dasar Negara RI 1945 hasil amandemen II, 2000.

Undang-Undang Nonmor 24 Tahun 2009 Tentang Bendera, Bahasa, Lambang dan Lagu Kebangsaan.

Peraturan Pemerintah Nomor 66 Tahun 1951 Tentang Lambang Negara.

Inpres Nomor 12 Tahun 1968 tentang Ucapan dan Tata Urutan Sila-sila Pancasila. 



\title{
MASALAH PENYIDIK DALAM TINDAK PIDANA JASA KEUANGAN DI INDONESIA
}

\author{
Wahyu Wiriadinata ${ }^{1}$
}

\begin{abstract}
The objective of this article is to answer the question on the effectiveness of the investigators of the Financial Service Authority (Otoritas Jasa Keuangan or OJK) in combating financial crime in Indonesia. The question and problems arise because in the OJK Law there is a type investigator that has authority to investigate crimes which include several sectors, namely banking, capital markets, insurance, pension fund, financing institutions, and the other financial institutions. On the other side, previously, there was the other type of investigators that has authority to investigate, namely the Attorney General Office, Police, and the Corruption Eradication Commission (Komisi Pemberantasan Korupsi or KPK). This study uses two theoretical frameworks: 1) Aristotles's notion on the objective of law to achieving justice; 2) Hans Kelsen's Stuffen Theory. The method to write this article is juridical-normative, through studying the regulations (peraturan perundang-undangan), either incorporated in the statutes itself or in the legal literatures, particularly set of regulations on OJK. The result is the juridical analysis that manifested in the form or descriptive analysis. The conclusion of this study is there will be an overlapping between the investigators of OJK and the other investigators from the Attorney General Office, Police, and KPK, either in the investigation of general crime or special crime/corruption, regarding the effectiveness of the investigators of OJK must be proven in the future.
\end{abstract}

Keywords: Investigators, financial services, effectiveness, overlapping

\begin{abstract}
Abstrak
Tulisan ini, bertujuan untuk menjawab pertanyaan sampai sejauh mana efektivitas penyidik Otoritas Jasa Keuangan (OJK) dalam menanggulangi kejahatan jasa keuangan di Indonesia. Pertanyaan dan masalah ini muncul karena dalam Undang-Undang Otoritas jasa Keuangan ada Penyidik OJK yang mempunyai kewenangan penyidikan terhadap tindak pidana OJK yang mencakup sektor perbankan, pasar modal, perasuransian, dana pensiun, lembaga pembiayaan, dan lembaga jasa keuangan lainnya. Padahal sudah ada penyidik lain yang mempunyai kewenangan untuk menyidik, yaitu Kejaksaan, Kepolisian dan KPK. Kerangka teoritis bertolak dari pemikiran Aristoteles yang mengemukakan tentang tujuan hukum untuk mencapai keadilan juga stuffen theory dari Hans Kelsen. Metode penulisan adalah yuridis normatif,

\footnotetext{
${ }^{1}$ Penulis adalah Staf Pengajar pada Fakultas Hukum Universitas Pasundan. Alamat kontak: wahyuwiriadinata@yahoo.co.id.
} 
dengan mempelajari peraturan perundang-undangan, baik yang ada dalam undang-undang itu sendiri maupun yang ada dalam literatur/buku ilmu pengetahuan hukum, khususnya perundang-undangan yang berkaitan dengan Otoritas Jasa Keuangan. Hasilnya berupa aspek yuridis dituangkan dalam bentuk deskriptif analitis. Adapun kesimpulan dari tulisan ini adalah : Akan terjadi tumpang tindih antara penyidik OJK dengan Penyidik Jaksa, Polisi dan KPK, baik dalam penyidikan tindak pidana umum maupun khusus/korupsi, tentang efektivitas dari penyidik OJK harus dibuktikan di masa yang akan datang.

Kata kunci: penyidik, jasa keuangan, efektivitas, tumpang tindih

\section{Pendahuluan}

Dalam rangka membangun perekonomian nasional yang tumbuh dengan stabil dan berkelanjutan, menciptakan keseimbangan di semua sektor perekonomian, serta memberikan kesejahteraan secara adil kepada seluruh rakyat Indonesia maka program pembangunan ekonomi nasional harus diwujudkan dengan menyeluruh dan bisa menggerakkan kegiatan perekonomian nasional yang memiliki jangkauan yang luas dan menyentuh ke seluruh sektor nyata. Salah satu komponen penting dalam sistem perekonomian nasional dimaksud adalah sistem keuangan dan seluruh kegiatan yang menjalankan fungsi perantara bagi berbagai kegiatan produktif di dalam perekonomian nasional.

Globalisasi ekonomi telah menciptakan sistem keuangan yang kompleks, dinamis, dan saling terkait antar-subsektor keuangan baik dalam hal produk maupun kelembagaan. Adanya lembaga jasa keuangan yang memiliki hubungan kepemilikan di berbagai subsektor keuangan telah menambah kompleksitas transaksi dan interaksi antarlembaga jasa keuangan di dalam sistem keuangan.

Banyaknya permasalahan lintas sektoral di sektor jasa keuangan, yang meliputi tindakan moral hazard, belum optimalnya perlindungan konsumen jasa keuangan, dan terganggunya stabilitas sistem keuangan semakin mendorong diperlukannya pembentukan lembaga pengawasan di sektor jasa keuangan yang terintegrasi.

Oleh karena itu, perlu dilakukan penataan kembali struktur pengorganisasian dari lembaga-lembaga yang melaksanakan tugas pengaturan dan pengawasan di sektor jasa keuangan yang mencakup sektor perbankan, pasar modal, perasuransian, dana pensiun, lembaga pembiayaan, dan lembaga jasa keuangan lainnya, agar dapat dicapai mekanisme koordinasi yang lebih efektif di dalam menangani permasalahan yang timbul dalam sistem keuangan sehingga dapat lebih menjamin tercapainya stabilitas sistem keuangan. Pengaturan dan pengawasan terhadap keseluruhan kegiatan jasa keuangan tersebut harus dilakukan secara terintegrasi.

Otoritas Jasa Keuangan diperlukan agar keseluruhan kegiatan jasa keuangan di dalam sektor keuangan terselenggara secara teratur, adil, 
transparan, dan akuntabel, serta mampu mewujudkan sistem keuangan yang tumbuh secara berkelanjutan dan stabil, dan mampu melindungi kepentingan konsumen dan masyarakat. Dengan tujuan ini, OJK diharapkan dapat mendukung kepentingan sektor jasa keuangan nasional sehingga mampu meningkatkan daya saing nasional. Selain itu, OJK harus mampu menjaga kepentingan nasional, antara lain, meliputi sumber daya manusia, pengelolaan, pengendalian, dan kepemilikan di sektor jasa keuangan, dengan tetap mempertimbangkan aspek positif globalisasi.

Otoritas Jasa Keuangan yang mandiri/independen dilandaskan asas-asas :

1. Independensi, yakni independen dalam pengambilan keputusan dan pelaksanaan fungsi, tugas, dan wewenang OJK, dengan tetap sesuai peraturan perundang-undangan yang berlaku;

2. Kepastian hukum, yakni asas dalam negara hukum yang mengutamakan landasan peraturan perundang-undangan dan keadilan dalam setiap kebijakan penyelenggaraan Otoritas Jasa Keuangan;

3. Kepentingan umum, yakni asas yang membela dan melindungi kepentingan konsumen dan masyarakat serta memajukan kesejahteraan umum;

4. Keterbukaan, yakni asas yang membuka diri terhadap hak masyarakat untuk memperoleh informasi yang benar, jujur, dan tidak diskriminatif tentang penyelenggaraan Otoritas Jasa Keuangan, dengan tetap memperhatikan perlindungan atas hak asasi pribadi dan golongan, serta rahasia negara, termasuk rahasia sebagaimana ditetapkan dalam peraturan perundang-undangan;

5. Profesionalitas, yakni asas yang mengutamakan keahlian dalam pelaksanaan tugas dan wewenang Otoritas Jasa Keuangan, dengan tetap berlandaskan pada kode etik dan ketentuan peraturan perundangundangan;

6. Integritas, yakni asas yang berpegang teguh pada nilai-nilai moral dalam setiap tindakan dan keputusan yang diambil dalam penyelenggaraan Otoritas Jasa Keuangan; dan

7. Akuntabilitas, yakni asas yang menentukan bahwa setiap kegiatan dan hasil akhir dari setiap kegiatan penyelenggaraan Otoritas Jasa Keuangan harus dapat dipertanggungjawabkan kepada publik.

Di Indonesia peran jasa keuangan pernah mengalami masa yang dinilai tidak melindungi masyarakat pengguna jasa keuangan, malah merugikan masyarakat dan negara, sebagaimana yang terjadi pada kasus/perkara Bantuan Likuiditas Bank Indonesia (BLBI).

Kasus BLBI merupakan masalah yang cukup mengguncangkan kondisi perbankan dan perekonomian Indonesia yang berimbas ke masalah politik dan hukum. Dalam kasus BLBI ini yang berawal dari 1997 banyak melibatkan para pejabat tinggi dari mulai Presiden Soeharto, Menteri Perekonomian dan Perindustrian, Menteri Keuangan, Menteri Sekretaris Negara, Pejabat Tinggi Bank Indonesia termasuk Anggota DPR masa jabatan 1999-2004 yang menangani Bidang Ekonomi dan Keuangan. Kasus ini bermula pada Agustus 
1997 ketika pemerintahan rejim Soeharto melepas sistem kurs mengambang terkendali (free floating). Masyarakat panik lalu belanja dollar dalam jumlah yang sangat besar. Setelah dana pemerintah ditarik ke Bank Indonesia, tingkat suku bunga di pasar uang dan deposito melonjak drastis karena bank-bank berebut dan menguras dana masyarakat. Pada 1 September 1997 Bank Indonesia menurunkan suku bunga SBI sebanyak tiga kali, kemudian muncul isu di masyarakat mengenai beberapa bank besar yang mengalami kalah kliring dan rugi dalam transaksi valuta asing. Hal ini menimbulkan tingkat kepercayaan masyarakat terhadap bank nasional goyah, sehingga terjadi rush. Atas fenomena ini, pemerintah akan membantu bank sehat yang mengalami kesulitan likuiditas, sedangkan bank yang sakit dimerger atau dilikuidasi. Kebijakan yang berupa kredit ini dinamakan Bantuan Likuiditas Bank Indonesia (BLBI). Pada 1 November 1997 ada 16 bank yang dilikuidasi, pada tanggal 31 Desember 1997 Bank Indonesia mulai membuka dan mengucurkan aliran dana besar-besaran ke bank-bank yang saat itu mengalami masalah keuangan yang nilainya mencapai kurang lebih 600 triliun. BLBI senilai kurang lebih 600 triliun itu ternyata oleh bank penerima bantuan malah diselewengkan, sehingga menjadi masalah pidana, menjadi perkara tindak pidana korupsi yang penanganannya dilakukan oleh Kejaksaan Agung Republik Indonesia.

Ada beberapa perkara BLBI ini yang melibatkan Bank besar yang perkaranya telah diputus dan dinyatakan para pimpinan bank tersebut terbukti melakukan tindak pidana korupsi. Akan tetapi perkara yang lainnya yang melibatkan konglomerat kakap ternyata perkaranya oleh Kejaksaan Agung dihentikan penyidikannya.

Akan tetapi terhadap penghentian penyidikan tersebut, Masyarakat Anti Korupsi Indonesia mengajukan praperadilan. Pada tanggal 6 Mei 2008 Pengadilan Negeri Jakarta Selatan mengabulkan permohonan praperadilan Masyarakat Anti Korupsi Indonesia terhadap surat perintah penghentian penyidikan (SP3) yang dikeluarkan Kejaksaan Agung atas kasus Bantuan Likuiditas Bank Indonesia (BLBI) Syamsul Nursalim. Kejaksaan Agung langsung menyatakan banding. Persoalannya terus menjadi polemik di antara para aparat penegak hukum (Kejaksaan, Kepolisian dan KPK), pemerintah dan para politisi di Dewan Perwakilan Rakyat. Kondisi yang tidak menentu ini jelas merugikan masyarakat konsumen pengguna jasa keuangan (perbankan) dan negara.

Demikian pula kasus Bank Century berawal dari kegagalan bank tersebut dalam memenuhi prefund kliring (transaksi antar bank) di Bank Indonesia pada 13 November 2008, seperti yang diakui oleh manajemen bank tersebut. Dalam pengakuannya, Manajemen Bank Century menyampaikan bahwa bank tersebut hanya terlambat 15 menit saat harus memenuhi dana prefund kliring sebesar Rp. 5 miliar yang seharusnya ditransfer pada pukul 08.00 WIB. Sehingga manajemen Bank Century mengumumkan bahwa pihaknya mengalami kalah kliring karena tingginya intensitas transaksi dana masuk dan dana keluar nasabah sehubungan dengan ketatnya likuiditas saat ini. Pada saat yang bersamaan, Muliaman D Hadad, Deputi Gubernur Bank Indonesia, mengaku 
tidak tahu-menahu mengenai hal tersebut. Dia mengatakan semua bank, baik besar maupun kecil, saat ini dalam pengawasan BI agar persoalan likuiditas ini bisa dikendalikan secara baik. Pada 21 November 2008, akhirnya Gubernur Bank Indonesia Boediono mengumumkan bahwa BI melalui Komite Stabilitas Sistem Keuangan (KKSK) memutuskan pengambilalihan Bank Century oleh Lembaga Penjamin Simpanan (LPS).

Meskipun Bank Indonesia menyadari bahwa kondisi kesehatan Bank Century dalam keadaan buruk, LPS meminta nasabah tak perlu panik karena lembaga tersebut akan menjamin seluruh kebutuhan likuiditas Bank Century dengan alokasi dana sebesar Rp. 1 triliun.

Berdasarkan data LPS, suntikan dana yang telah dikucurkan oleh lembaga tersebut kepada Bank Century total dana yang dikucurkan adalah Rp. 6,77 triliun.

Bukti ketidak-beresan manajemen Bank Century dalam menjalankan operasionalnya semakin terlihat ketika ditetapkannya status tersangka kepada mantan Direktur Utama Bank Century, Hermanus Hasan Muslim pada 27 November 2008. berdasarkan pemeriksaan penyidik Polisi, Hermanus telah melanggar tindak pidana perbankan. Hermanus terbukti telah menjalankan permintaan dari tersangka sebelumnya yaitu Robert Tantular.

Kasus Bank Century ternyata tidak sekedar masalah internal, ternyata dugaan atas lemahnya pengawasan dan koordinasi antara Bank Indonesia dan Bapepam-LK terbukti dengan mencuatnya masalah penggelapan dana investasi PT Antaboga Sekuritas di Bank Century. Perusahaan yang berdiri sejak tahun 1989 ini diadukan para nasabah ke Badan Pengawas Pasar Modal dan Lembaga Keuangan (Bapepam-LK). Beberapa manajemen perusahaan itu diduga menggelapkan uang milik investor. Kerugian sementara yang diderita para investor adalah Rp. 233 miliar. Kerugian ini, menurut Polisi kemungkinan akan bertambah.

Kisruh di Antaboga berawal dari kasus yang terjadi di PT. Bank Century Tbk, ketika operasional Bank Century diambil alih oleh Lembaga Penjamin Simpanan (LPS), ratusan nasabah Antaboga mendatangi kantor perusahaan tersebut. Mereka ingin menarik dananya yang diinvestasikan di reksadana. Pasalnya, produk investasi yang diterbitkan Antaboga, dipasarkan oleh Bank Century. Nasabah Antaboga kebanyakan adalah nasabah Bank Century. Mereka diminta menandatangani sertifikat reksadana di kantor Bank Century.

Dengan adanya kasus Bank Century yang sekarang berubah nama menjadi Bank Mutiara telah ada pimpinan Bank Century yang dipidana, akan tetapi kasus yang lain yang kerugian negaranya lebih besar dan melibatkan para petinggi dan penguasa di Indonesia, kasusnya belum terselesaikan dengan tuntas.

Adapun kasus pencucian uang yang merugikan konsumen jasa keuangan di masyarakat antara lain kasus Dhana Widyatmika dijerat dengan Pasal 55 ayat 1, Pasal 3 dan 4 UU No. 8/2010 tentang Pencegahan dan Pemberantasan Tindak Pidana Pencucian Uang.

Dhana Widyatmika diduga memiliki berbagai usaha untuk melakukan pencucian uang, antara lain memiliki perusahaan PT. Mitra Modern Mobilindo 
(jual beli mobil), PT. Bangun Bumi Persada (real estate), PT. Trisula Artamega (perdagangan); memiliki beberapa kapling tanah senilai Rp. 4,5 miliar, minimarket dan peternakan ayam. Ditemukan dalam satu rekening terdapat aliran dana senilai Rp. 97 miliar. Dhana diduga memiliki kekayaan senilai Rp. 60 miliar.

Kasus Dhana Widyatmika ini sekarang sedang ditangani oleh penyidik Kejaksaan Agung RI, akan tetapi kasus lain yang terkait yang melibatkan para pejabat tinggi di Departemen Keuangan dan nilai pencucian uangnya lebih dari kasus Dhana, nampaknya belum disentuh oleh aparat penegak hukum.

Untuk menjawab, menyelesaikan dan mencegah kasus-kasus tersebut di atas tidak terulang kembali. Pemerintah dan negara telah mengambil langkahlangkah pencegahan, antara lain dengan diundangkannya Undang-Undang Nomor 21 Tahun 2011 tentang Otoritas Jasa Keuangan (OJK). Sebagai pelengkap atau menyempurnakan peraturan perundang-undangan yang mempunyai fungsi dan tujuan yang sama dengan undang-undang OJK yaitu undang-undang tentang Bank Indonesia. Dalam Undang-Undang Nomor 21 tahun 2011 tersebut secara khusus diberikan wewenang kepada penyidik OJK untuk melakukan penyidikan terhadap kejahatan OJK. Undang-undang tentang Bank Indonesia mempunyai fungsi dan tujuan antara lain melindungi kepentingan konsumen jasa keuangan di masyarakat, walaupun setelah sekian lama undang-undang tentang Bank Indonesia berlaku, perlindungan terhadap konsumen tetap lemah, dengan indikasi beberapa kasus seperti yang telah dibeberkan di atas.

Selain itu dengan lahirnya undang-undang tentang otoritas jasa keuangan, dimana otoritas jasa keuangan mempunyai fungsi juga tentang pengawasan terhadap perbankan, sedangkan dalam undang-undang Bank Indonesia Pasal 8 c: Untuk mencapai tujuan sebagaimana dimaksud dalam Pasal 7, Bank Indonesia mempunyai tugas sebagai berikut: c. mengatur dan mengawasi Bank. Dengan demikian terjadi tumpang tindih dalam pengawasan terhadap OJK khususnya di sektor Perbankan. Begitu pula tentang penyidik OJK dan menemukan problema yang sama di mana yang akan datang, sebab akan terjadi over lap dengan penyidik yang ada yaitu penyidik Kejaksaan, Kepolisian dan KPK.

Dari uraian tersebut di atas muncul pertanyaan yang perlu dilakukan pengkajian yaitu: Sejauh mana efektivitas dari penyidik OJK dalam menanggulangi kejahatan Jasa Keuangan di Indonesia.

Untuk mengurai pertanyaan di atas dan menjawab permasalahan yang telah dirumuskan, digunakan metode penelitian, yaitu penelitian hukum normatif/yuridis normatif, data yang diperoleh dianalisis secara deskriptif kualitatif. Analisis deskriptif kualitatif yaitu metode analisis data yang mengelompokkan dan menyeleksi data primer berupa undang-undang, kemudian dihubungkan dengan teori-teori, asas-asas, dan kaidah-kaidah hukum yang diperoleh dari studi kepustakaan sehingga diperoleh jawaban atas permasalahan yang dirumuskan.

Adapun guna tulisan ini ialah mudah-mudahan berguna bagi dunia ilmu pengetahuan hukum pada khususnya dan ilmu pengetahuan pada umumnya. 


\section{Landasan Pemikiran}

Aliran hukum alam didasari oleh pemikiran filosofis dari Aristoteles, dijelaskan bahwa pengertian adil menurut undang-undang dan adil menurut alam. Hukum alam berlaku di semua ruang dan sifatnya tidak tertulis. Lebih lanjut ditegaskan hubungan antara hukum alam dengan hukum positif. Aristoteles mengemukakan bahwa derajat hukum alam itu lebih tinggi dibandingkan hukum positif. Hukum alam itu melengkapi kekurangankekurangan yang dialami oleh hukum positif. Melengkapi kekurangankekurangan yang dialami oleh hukum positif. Hukum alam membawa kelayakan, melunakkan satu ketentuan umum yang terdapat dalam setiap peraturan perundang-undangan dengan memperhitungkan keadaan-keadaan tertentu dari tiap-tiap permasalahan. Namun demikian tidak berarti bahwa adil menurut kepatutan adalah tidak adil menurut undang-undang, akan tetapi kepatutan memberikan kesempurnaan. ${ }^{2}$

Pasca Aristoteles pemikiran tentang hukum alam atau hukum kodrat berkembang lebih jauh. Thomas Aquinas adalah salah satu pemikir hukum alam pasca Aristoteles yang pemikirannya lahir pada abad pertengahan yang cukup besar pengaruhnya terutama di kalangan kaum gereja Katholik bahkan sampai abad ke 21 ini, hal tersebut terlihat pada pembaharuan filsafatnya oleh pakar-pakar hukum khususnya yang beragama Katholik yang disebut aliran Neo-Thomistis. Berbeda dengan pandangan M.T. Cicero, Thomas Aquinas sebenarnya membedakan antara enam macam hukum, yaitu : hukum abadi (lex aeterna), hukum kodrat (lex naturalis), hukum manusia (lex humana), hukum Ilahi (lex devina), hukum yang diberikan oleh gereja kepada kaum beriman, kristiani (lex ecclesiastica), dan hukum nafsu, dorongan nafsu-nafsu dalam diri kita yang merangsang kita untuk berdoa (lex concupiscential). Pada abad pertengahan tersebut hukum alam dicirikan dengan bersumberkan dari rasio Tuhan.

Selanjutnya hukum alam dalam keragaman dan manifestasinya terlihat pada jaman Aufklarung (pencerahan), Thomas Hobbes mengartikan hukum alam sebagai susunan aturan-aturan yang harus dipakai sebagai pedoman bagi kemajuan seseorang menurut cita-cita rasionalnya, jika ia dapat mengetahui dengan sempurna semua keadaan yang meliputinya dan sama sekali tidak tergoncangkan oleh perasaan-perasaan yang mendadak dan prasangkaprasangka. Karena itu menurut anggapan sebagian besar manusia benar-benar bertindak demikian, maka aturan-aturan hukum alam secara hipotetis menetapkan syarat-syarat sebagai dasar yang memungkinkan tingkah laku manusia yang pokok untuk mendirikan suatu pemerintah yang kokoh. Aturanaturan tersebut bukanlah menentukan adat nilai, melainkan menetapkan secara sebab-akibat dan ajaran-ajaran hukum dan moral. Selanjutnya Thommas Hobbes berpendapat bahwa hukum alam fundamentil, yang pertama ialah mencari damai dan mengikutinya, manusia diperintahkan berusaha memperoleh damai dan keadilan, sejalan dengan alam pikiran Aristoeles.

\footnotetext{
${ }^{2}$ Roscoe Pound, "Pengantar Filsafat Hukum”, (Jakarta: Bharata, 1972), hal. 14.
} 
Akan halnya pemikiran dari aliran hukum positif/recht positivisme. Aliran positifisme ini sangat mengagungkan hukum tertulis. Aliran ini beranggapan bahwa tidak ada norma hukum di luar hukum positif, semua persoalan dalam masyarakat diatur dalam hukum tertulis. ${ }^{3}$

Tokoh yang paling berpengaruh dari aliran ini adalah Hans Kelsen. Menurutnya teori hukum murni adalah hukum positif. Ini merupakan teori tentang hukum positif umum, bukan penafsiran tentang norma hukum nasional atau internasional tertentu, namun ia menyajikan teori penafsiran. Pandangan Kelsen tentang hukum, sangat mencerminkan ciri positivisnya. Kelsen melihat hukum positif sebagai satu-satunya hukum, dan hukum harus benar-benar dipisahkan dari segala pengaruh anasir-anasir non hukum, seperti moral, politis, ekonomis, sosiologis, dan sebagainya. Kelsen selain dikenal sebagai pencetus teori hukum murni tapi berjasa mengembangkan teori jenjang (stuffen theory) yang semula dikemukakan oleh Adolf Merkl. Teori ini melihat hukum sebagai suatu sistem yang terdiri dari susunan norma berbentuk piramida. Norma yang lebih rendah memperoleh kekuatannya dari yang lebih tinggi. Semakin tinggi suatu norma semakin abstrak sifatnya, sebaliknya semakin rendah kedudukannya semakin konkrit norma tersebut. Norma yang paling tinggi di sebut oleh Kelsen dengan Grundnorm atau norma dasar. Pandangan semacam ini sudah tidak relevan lagi dalam masa modern kini. Tak mungkin kita menjadikan hukum sebagai sesuatu "benda otonom" yang berdiri terlepas sama sekali dari pengaruh ekonomi, politik, sosial dan budaya. Hukum tidak berada dalam ruangan hampa, tapi dia selalu berinteraksi dengan lingkungan sekelilingnya lebih-lebih di abad globalisasi ini. Demikianlah dalam UndangUndang OJK yang mengatur tersendiri tentang penyidikan yaitu dengan membentuk dan memberi kewenangan penyidikan terhadap tindak pidana OJK kepada penyidik tersendiri di luar penyidik yang telah ada sebelumnya, yaitu Jaksa, Polisi dan KPK dilakukan dengan maksud untuk adanya keseimbangan antara tujuan hukum untuk mencapai keadilan dan tujuan hukum untuk mencapai kepastian hukum.

\section{Pembahasan}

Dari landasan pemikiran di atas, maka kita dapat mengambil satu makna, sesungguhnya hukum itu terbentuk tidak lain adalah untuk menciptakan keadilan di samping adanya kepastian hukum. Tentang hukum yang bertujuan mencapai keadilan di masyarakat itu dilukiskan oleh Muchtar Kusumaatmadja dalam definisi hukumnya :

Hukum adalah keseluruhan asas dan kaidah yang mengatur pergaulan hidup manusia dalam masyarakat yang bertujuan untuk memelihara ketertiban dan mencapai keadilan, juga meliputi lembaga

3 Roelan Saleh, "Mengadili Sebagai Pergaulan Kemanusiaan", (Jakarta: Aksara Baru, 1983), hal. 77. 
serta proses yang mewujudkan berlakunya kaidah tersebut sebagai kenyataan di masyarakat. ${ }^{4}$

Dari definisi di atas Muchtar Kusumaatmadja menggaris bawahi bahwa sebelum tercapainya keadilan harus diciptakan dulu ketertiban di masyarakat, tidak mungkin ada keadilan kalau masyarakat tidak tertib. Artinya masyarakat harus mentaati hukum, baik hukum materil maupun hukum formil. Yang dimaksud dengan ketertiban di sini termasuk ketertiban dalam proses peradilan. Mulai penyidikan, pra-penuntutan, penuntutan, persidangan dan eksekusi. Termasuk di dalamnya proses dan penyelesaian perkara tindak pidana Otoritas Jasa Keuangan.

Tentang penyidikan, Pasal 1 butir 1 KUHAP menyebutkan, penyidik adalah pejabat polisi negara Republik Indonesia atau pejabat pegawai Negeri Sipil tertentu yang diberi wewenang khusus oleh undang-undang untuk melakukan penyidikan.

Pengangkatan untuk menjabat jabatan sebagai penyidik Polisi adalah berdasarkan penunjukan oleh Kepala Kepolisian RI (Kapolri).

Wewenang untuk menunjuk penyidik tersebut dapat dilimpahkan oleh Kapolri kepada Pejabat Kepolisian Negara RI. Sedangkan penyidik yang dijabat oleh Pegawai Negeri Sipil, pengangkatannya dilakukan oleh Menteri atas usul Departemen yang membawahi Pegawai Negeri Sipil tersebut. Mentri sebelum melaksanakan pengangkatan terlebih dahulu mendengarkan pertimbangan Jaksa Agung dan Kepala Kepolisian RI. Dan wewenang pengangkatan itu dapat dilimpahkan oleh Menteri Kepada Pejabat yang ditunjuknya. (Pasal 2 (6) PPRI No. 27/1983).

Pengangkatan seseorang menjadi penyidik pembantu, yang berasal dari kepolisian diangkat oleh Kepala Kepolisian RI atas usul dari komandan atau pimpinan kesatuannya masing-masing. Sedangkan pengangkatan Penyidik Pembantu yang berasal dari Pegawai Negeri Sipil dapat dilimpahkan kepada pejabat Kepolisian Negara RI.

(1) Penyidikan adalah tindakan selama pemeriksaan pendahuluan untuk mencari bukti-bukti tentang tindak pidana;

(2) Penyidikan dilakukan oleh:

a. Penyidik yang dijabat oleh pejabat Kepolisian Negara yang berpangkat sekurang-kurangnya Pembantu Letnan Dua;

b. Pembantu penyidik yang dijabat oleh pejabat Kepolisian Negara, yang berpangkat Sersan Dua sampai dengan Sersan Mayor dan anggotaanggota kepolisian khusus yang atas usul Komandan atau Kepala Jawatan Instansi Sipil pemerintah diangkat oleh Kapolri.

\footnotetext{
${ }^{4}$ P. Sitorus, "Pengantar Ilmu Hukum (Dilengkapi Tanya Jawab)", (Bandung: Pasundan Law Faculty, Alumnus Press, 1998), hal. 94.
} 
Yang dimaksud dengan Polisi Khusus, adalah pejabat-pejabat dari instansi/jawatan sipil tertentu yang diberi kewenangan Kepolisian khusus oleh undang-undang.

Selain itu ada juga penyidik tindak pidana tertentu, seperti penyidik tindak pidana tertentu/khusus yaitu penyidik Jaksa dan KPK yang melakukan penyidikan terhadap tindak pidana khusus korupsi.

Demikianlah Undang-undang Otoritas Jasa Keuangan yang mengatur tentang acara sendiri khususnya perihal penyidikan. Hal ini akan menimbulkan pertanyaan akankah terjadi penyidikan oleh penyidik OJK di dalam tindak pidana yang sama, dimana hak dan kewenangan penyidikan pada tindak pidana OJK dipunyai juga oleh penyidik lain yang telah ada. Keadaan ini nampaknya akan tidak selaras dengan integrated criminal justice system. Integrated criminal justice system mempunyai pengertian adanya keterpaduan penyidik bidang tindak pidana. Salah satu pilar dari sistem penanganan terpadu, adalah harus adanya koordinasi dari para penyidik. ${ }^{5}$

Dengan adanya penyidik Otoritas Jasa Keuangan, hal ini akan menimbulkan rebutan perkara dalam penyidikan tindak pidana OJK dan akan terjadi tumpang tindih kewenangan yang berujung kepada adanya nebis in idem.

Otoritas Jasa Keuangan (OJK) adalah lembaga yang mandiri dan independen serta bebas dari campur tangan pihak lain, yang mempunyai fungsi, tugas dan wewenang pengaturan, pengawasan, pemeriksaan, dan penyidikan di sektor perbankan, pasar modal, pengasuransian, dana pensiun, lembaga pembayaran dan lembaga keuangan lainnya. Dengan demikian termasuk penyidikan terhadap tindak pidana korupsi, perdagangan obat bius, perdagangan senjata dan manusia, penyelundupan, kejahatan di bidang perpajakan, pasar modal dan kejahatan di industri asuransi. Itu dapat disidik oleh penyidik OJK apabila terindikasi adanya kejahatan.

Dengan demikian penyidik OJK mempunyai kewenangan yang besar selain berwenang melakukan penyidikan yang tidak dipunyai oleh penyidik lain.

Dalam hal penyidikan terhadap tindak pidana jasa keuangan undangundang OJK mengaturnya dalam Pasal 49 yang berbunyi:

(1) Selain Pejabat Penyidik Kepolisian Negara Republik Indonesia, Pejabat Pegawai Negeri Sipil tertentu yang lingkup tugas dan tanggung jawabnya yang meliputi pengawasan sektor jasa keuangan di lingkungan OJK, diberi wewenang khusus sebagai penyidik sebagaimana dimaksud dalam Kitab Undang-Undang Hukum Acara Pidana.

(2) Pegawai negeri sebagaimana dimaksud dalam Pasal 27 ayat (2) dapat diangkat menjadi Penyidik Pegawai Negeri Sipil sebagaimana dimaksud pada ayat (1).

\footnotetext{
5 Barda Nawawi Arief, "Bunga Rampai Kebijakan Hukum Pidana", Cetakan Kesatu, (Bandung: Penerbit PT. Citra Aditya Bakti, 1996), hal. 61.
} 
(3) Penyidik Pegawai Negeri Sipil sebagaimana dimaksud pada ayat (1) berwenang:

a. menerima laporan, pemberitahuan, atau pengaduan dari seseorang tentang adanya tindak pidana di sektor jasa keuangan;

b. melakukan penelitian atas kebenaran laporan atau keterangan berkenaan dengan tindak pidana di sektor jasa keuangan;

c. melakukan penelitian terhadap Setiap Orang yang diduga melakukan atau terlibat dalam tindak pidana di sektor jasa keuangan;

d. memanggil, memeriksa, serta meminta keterangan dan barang bukti dari Setiap Orang yang disangka melakukan, atau sebagai saksi dalam tindak pidana di sektor jasa keuangan;

e. melakukan pemeriksaan atas pembukuan, catatan, dan dokumen lain berkenaan dengan tindak pidana di sektor jasa keuangan;

f. melakukan penggeledahan di setiap tempat tertentu yang diduga terdapat setiap barang bukti pembukuan, pencatatan, dan dokumen lain serta melakukan penyitaan terhadap barang yang dapat dijadikan bahan bukti dalam perkara tindak pidana di sektor jasa keuangan;

g. meminta data, dokumen, atau alat bukti lain, baik cetak maupun elektronik kepada penyelenggara jasa telekomunikasi;

h. dalam keadaan tertentu meminta kepada pejabat yang berwenang untuk melakukan pencegahan terhadap orang yang diduga telah melakukan tindak pidana di sektor jasa keuangan sesuai dengan ketentuan peraturan perundang-undangan;

$i$. meminta bantuan aparat penegak hukum lain;

j. $\quad$ meminta keterangan dari bank tentang keadaan keuangan pihak yang diduga melakukan atau terlibat dalam pelanggaran terhadap peraturan perundang-undangan di sektor jasa keuangan;

k. memblokir rekening pada bank atau lembaga keuangan lain dari pihak yang diduga melakukan atau terlibat dalam tindak pidana di sektor jasa keuangan;

l. meminta bantuan ahli dalam rangka pelaksanaan tugas penyidikan tindak pidana di sektor jasa keuangan; dan

m. menyatakan saat dimulai dan dihentikannya penyidikan.

Penyidik sebagaimana dimaksud dalam Pasal 49 menyampaikan hasil penyidikan kepada Jaksa untuk dilakukan penuntutan dan Jaksa wajib menindaklanjuti dan memutuskan tindak lanjut hasil penyidikan sesuai kewenangannya paling lama 90 (sembilan puluh) hari sejak diterimanya hasil penyidikan sebagaimana dimaksud pada ayat (1).

Tentang kewenangan penyidikan yang dipunyai oleh penyidik OJK ini, seperti penyidikan terhadap semua tindak pidana yang menyangkut jasa keuangan seperti diatur dalam sektor perbankan, pasar modal, perasuransian, dana pensiun, lembaga pembiayaan. Sementara terhadap tindak pidana 
perbankan telah ada penyidik sebelumnya yaitu pejabat Polisi Negara, Jaksa dan KPK.

Polisi sebagai penyidik tindak pidana - perbankan - diatur dalam Undang-Undang Nomor 8 Tahun 1981 tentang KUHAP Pasal 6 ayat (1) a. Penyidik adalah Polisi Negara Republik Indonesia, selain itu Polisi sebagai penyidik diatur pula dalam Undang-Undang Nomor 2 Tahun 2002 tentang Kepolisian RI Pasal 14 ayat (1) a:

Melaksanakan penyelidikan dan penyidikan terhadap semua tindak pidana sesuai dengan hukum acara pidana dan peraturan perundangundangan lainnya.

Dengan demikian Polisi sebagai penyidik termasuk penyidik mempunyai hak dan kewenangan untuk melakukan penyidikan terhadap semua tindak pidana, termasuk tindak pidana di sektor jasa keuangan (Perbankan dan lainlain).

Begitu juga Kejaksaan. Jaksa sebagai penyidik mempunyai kewenangan melakukan penyidikan terhadap tindak pidana tertentu seperti tindak pidana korupsi, ini diatur dalam Undang-Undang Nomor 16 Tahun 2004 tentang Kejaksaan Republik Indonesia Pasal 30 ayat (1) d. Di bidang Pidana Kejaksaan mempunyai tugas dan wewenang melakukan penyidikan terhadap tindak pidana tertentu berdasarkan undang-undang.

Jadi apabila terindikasi adanya tindak pidana korupsi di sektor jasa keuangan (sektor perbankan dan lain-lain) maka Jaksa berwenang melakukan penyidikan. Begitu juga penyidik KPK, selaku penyidik mempunyai kewenangan penyidikan terhadap tindak pidana korupsi, seperti diatur dalam Undang-Undang Nomor 30 Tahun 2002 tentang Komisi Pemberantasan Korupsi Pasal 6 c):

Komisi Pemberantasan Korupsi mempunyai tugas : Melakukan penyelidikan, penyidikan dan penuntutan terhadap tindak pidana korupsi.

Dengan demikian penyidik KPK mempunyai kewenangan pula di sektor perbankan dan sektor-sektor otoritas jasa keuangan lainnya, apabila di sektorsektor itu terindikasi adanya tindak pidana korupsi.

Dengan adanya kewenangan penyidikan dari penyidik OJK, maka akan terjadi diverifikasi penyidik dan akan membuat makin tumpang tindihnya penyidikan dalam tindak pidana tertentu yaitu tindak pidana yang diatur di luar KUHAP.

Kasus BLBI yang tak kunjung tuntas, juga kasus Bank Century yang sudah ditangani oleh penyidik KPK, Kepolisian dan Kejaksaan sampai hari ini belum mengakomodir aspirasi masyarakat secara tuntas. Kasus mutakhir tentang tumpang tindihnya penyidikan, adalah dalam kasus/ perkara simulator SIM yang sama-sama ditangani oleh penyidik yaitu penyidik Kepolisian dan Penyidik KPK. 
Akankah penyidik OJK efektif melaksanakan pemberantasan tindak pidana di bidang OJK. Pertanyaan pada awal tulisan ini harus dibuktikan di waktu yang akan datang, sebab kewenangan penyidikannya pun baru akan dijalankan.

\section{Kesimpulan}

1. Untuk melindungi masyarakat terhadap kejahatan jasa keuangan, maka dibuatlah undang-undang tentang jasa keuangan, yaitu Undang-Undang Nomor 21 Tahun 2011. Adapun tugas dan kewenangan OJK adalah antara lain melakukan pengawasan terhadap kegiatan jasa keuangan, selain daripada itu OJK juga mempunyai kewenangan untuk melakukan penindakan terhadap tindak pidana jasa keuangan, yaitu dengan membentuk penyidik tersendiri yaitu penyidik OJK di luar penyidik yang telah ada seperti Penyidik Polisi, Jaksa dan KPK.

2. Dengan lahirnya Undang-Undang Nomor 21 Tahun 2011 tentang Otoritas Jasa Keuangan dimana di dalamnya mengatur tentang penyidik tersendiri, maka dimungkinkan akan terjadi tumpang tindih penyidikan. Baik penyidikan tindak pidana umum maupun tindak pidana khusus. Sebab terhadap tindak pidana yang terjadi dalam Otoritas Jasa Keuangan diatur oleh ketentuan undang-undang yang ada dan telah ada penyidik lain yang berhak melakukan penyidikannya.

Polisi sebagai penyidik tindak pidana - perbankan - diatur dalam Undang-Undang Nomor 8 Tahun 1981 tentang KUHAP Pasal 6 ayat (1) a. Penyidik adalah Polisi Negara Republik Indonesia, selain itu Polisi sebagai penyidik diatur pula dalam Undang-Undang Nomor 2 Tahun 2002 tentang Kepolisian RI Pasal 14 ayat (1) a :

Melaksanakan penyelidikan dan penyidikan terhadap semua tindak pidana sesuai dengan hukum acara pidana dan peraturan perundangundangan lainnya.

Dengan demikian Polisi sebagai penyidik termasuk penyidik mempunyai hak dan kewenangan untuk melakukan penyidikan terhadap semua tindak pidana, termasuk tindak pidana di sektor jasa keuangan (Perbankan dan lain-lain).

Begitu juga Kejaksaan. Jaksa sebagai penyidik mempunyai kewenangan melakukan penyidikan terhadap tindak pidana tertentu seperti tindak pidana korupsi, ini diatur dalam Undang-Undang Nomor 16 Tahun 2004 tentang Kejaksaan Republik Indonesia Pasal 30 ayat (1) d. Di bidang Pidana Kejaksaan mempunyai tugas dan wewenang melakukan penyidikan terhadap tindak pidana tertentu berdasarkan undangundang.

Jadi apabila terindikasi adanya tindak pidana korupsi di sektor jasa keuangan (sektor perbankan dan lain-lain) maka Jaksa berwenang melakukan penyidikan. Begitu juga penyidik KPK, selaku penyidik mempunyai kewenangan penyidikan terhadap tindak pidana korupsi, 
seperti diatur dalam Undang-Undang Nomor 30 Tahun 2002 tentang Komisi Pemberantasan Korupsi Pasal 6 c) :

Komisi Pemberantasan Korupsi mempunyai tugas : Melakukan penyelidikan, penyidikan dan penuntutan terhadap tindak pidana korupsi.

Dengan demikian penyidik KPK mempunyai kewenangan pula di sektor perbankan dan sektor-sektor otoritas jasa keuangan lainnya, apabila di sektor-sektor itu terindikasi adanya tindak pidana korupsi.

3. Tentang efektivitas dari penyidik Otoritas Jasa Keuangan harus dibuktikan di masa yang akan datang. Karena kewenangan yang dipunyai oleh penyidik Otoritas Jasa Keuangan sampai saat ini belum dilaksanakan. Oleh karena itu hasil dan efektivitasnya belum dapat dievaluasi dan diukur. 


\section{Daftar Pustaka}

Adji, Oemar Seno. Hukum (Acara) Pidana dalam Prospeksi, Jakarta: Erangga, 1976.

Arief, Barda Nawawi. Bunga Rampai Kebijakan Hukum Pidana, Cetakan Kesatu, Bandung: Penerbit PT. Citra Aditya Bakti, 1996.

Bonn, E. Sosrodanukusumo. Tunutan Pidana, Djakarta: Penerbit Siliwangi, tanpa tahun.

Hamzah, Andi. Hukum Acara Pidana Indonesia, Jakarta: Sinar Grafika 2006.

Pound, Roscoe. Pengantar Filsafat Hukum, Jakarta: Bharata, 1972.

Prodjodikoro, Wirjono. Hukum Atjara Pidana di Indo, Djakarta: Penerbit Sumur Bandung, 1967.

Saleh, Roelan. Mengadili Sebagai Pergaulan Kemanusiaan, Jakarta: Aksara Baru, 1983.

Sitorus, P. Pengantar Ilmu Hukum (dilengkapi tanya jawab, Pasundan Law Faculty, Bandung: Alumnus Press, 1998.

Soedjono D. Pemeriksaan Pendahuluan Menurut KUHAP. Bandung: Alumni, 1982.

Tahir, Hadari Djenawi. Pokok-Pokok Pikian dalam KUHAP. Bandung: Alumni, 1981.

Tanusuboto, S. Peranan Praperadilan dalam Hukum Acara Pidana. Bandung: Alumni, 1981.

Tresna, R. Komentar HIR. Djakarta: Pradnya Paramita, tanpa tahun.

\section{Undang-Undang}

Undang-Undang Nomor 8 Tahun 1981, tentang Hukum Acara Pidana.

Undang-Undang Nomor 31 Tahun 1999, tentang Pemberantasan Tindak Pidana Korupsi.

Undang-Undang Nomor 21 Tahun 2011, tentang Otoritas Jasa Keuangan. 